Research Article

Alan Bischoff*, Andrew Nicol, Jim Cole, and Darren Gravley

\title{
Stratigraphy of Architectural Elements of a Buried Monogenetic Volcanic System
}

https://doi.org/10.1515/geo-2019-0048

Received May 14, 2019; accepted Sep 09, 2019

\begin{abstract}
Large volumes of magma emplaced and deposited within sedimentary basins can have an impact on the architecture and geological evolution of these basins. Over the last decade, continuous improvement in techniques such as seismic volcano-stratigraphy and 3D vi-
\end{abstract} sualisation of igneous bodies has helped increase knowledge about the architecture of volcanic systems buried in sedimentary basins. Here, we present the complete architecture of the Maahunui Volcanic System (MVS), a middle Miocene monogenetic volcanic field now buried in the offshore Canterbury Basin, South Island of New Zealand. We show the location, geometry, size, and stratigraphic relationships between 25 main intrusive, extrusive and sedimentary architectural elements, in a comprehensive volcano-stratigraphic framework that explains the evolution of the MVS from emplacement to complete burial in the host sedimentary basin. Understanding the relationships between these diverse architectural elements allows us to reconstruct the complete architecture of the MVS, including its shallow $(<3 \mathrm{~km})$ plumbing system, the morphology of the volcanoes, and their impact in the host sedimentary basin during their burial. The plumbing system of the MVS comprises saucer-shaped sills, dikes and sill swarms, minor stocks and laccoliths, and pre-eruptive strata deformed by intrusions. The eruptive and associated sedimentary architectural elements define the morphology of volcanoes in the MVS, which comprise deep-water equivalents of crater and cone-type volcanoes. After volcanism ceased, the process of degradation and burial of volcanic edifices formed sedimentary architectural elements such as inter-cone plains, epiclastic plumes, and canyons. Insights from the architecture of the MVS can be used to explore for natural resources such as hydrocarbons, geother-

\footnotetext{
*Corresponding Author: Alan Bischoff: Department of Geological Sciences, University of Canterbury, Christchurch, New Zealand; Email: alan.bischoff@canterbury.ac.nz

Andrew Nicol, Jim Cole, Darren Gravley: Department of Geological Sciences, University of Canterbury, Christchurch, New Zealand
}

mal energy and minerals in buried and active volcanic systems elsewhere.

Keywords: buried volcanoes; monogenetic volcanic system; seismic reflection; volcanic architectural elements

\section{Introduction}

Volcanoes buried in sedimentary basins typically form complex magmatic-sedimentary systems [1-6]. The largescale architecture of buried volcanoes can be broadly divided into two realms: endogenous and exogenous. In the endogenous realm, magma emplaced within sedimentary strata can form a variety of intrusive bodies, each with different morphologies, sizes and contact relationships with the host rocks, typically controlled by the equilibrium between magma pressure and lithostatic pressure [7-10]. In contrast, magma that reaches the Earths' surface (the exogenous realm) typically produces diverse terrestrial and subaqueous morphologies, which are defined by the interplay of dynamic processes, such as eruptive styles, edifice growth mechanisms, magma composition, the nature of the eruptive environment, and tectonic settings [11-15].

The multitude of intrusive, eruptive and sedimentary bodies present in buried volcanoes can complicate their architectural characterisation [4, 6, 16-20]. Studies that describe the morphology (the form) and architecture (the arrangement of the parts) of monogenetic volcanoes are well constrained from the interpretation of modern and ancient outcropping systems [11, 13, 21-25]. However, complete architectural characterisation based on outcrop observations of both endogenous and exogenous parts of monogenetic fields are only possible in rare exhumed volcanic fields [26, 27]. This is especially true for the deep diatreme zones that lay beneath small volume maar volcanoes $[28,29]$. Therefore, significant research is necessary to understand the key processes that collectively control volcanic and sub-volcanic architecture. High-quality 2D and 3D seismic surveys can provide a valuable opportunity to observe buried volcanic systems on outcrop to regional seismic scales $[5,15,30,31]$. This approach can be en- 


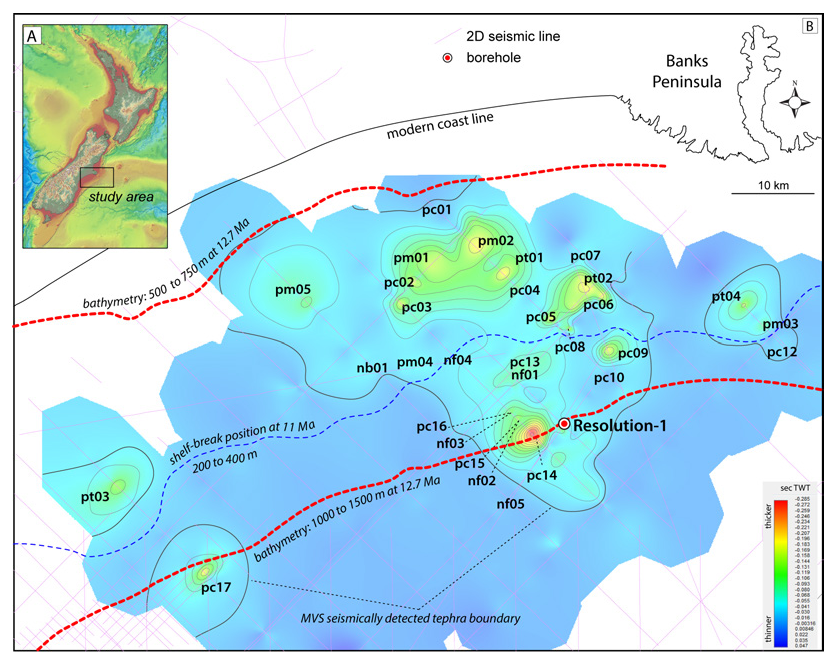

Figure 1: A) Location of the study area on a New Zealand topographic and bathymetric map (from Petroleum Exploration 2018 datapack). B) Paleogeography of the Maahunui Volcanic System. The names of each volcanic edifice in the MVS are shown on the map. Abbreviations for each volcanic element are: pc (positive cone), pt (positive trapezium), pm (positive mounds) represent cone-type volcanoes, $\mathrm{nf}$ (negative funnel-like) and nb (negative basin-like) correspond to crater-type volcanoes. Red dashed lines show the approximate bathymetry at the onset of eruptions in the MVS. The blue dashed line shows the position of the shelf-break at 11 Ma. Modified from [40].

riched by coupling the seismic data with information from borehole samples, wireline data, and laboratory experiments [3, 32]. Currently, few studies have been conducted aiming to characterise the complete architecture of buried monogenetic volcanic systems, including their plumbing system, eruptive deposits, and the sedimentary strata that enclose them [33, 34]. Here, we adapt the approach presented in [6] for characterizing the architecture of polygenetic buried volcanic systems to unravel the complete architecture of the Maahunui Volcanic System (MVS), a submarine monogenetic volcanic field currently buried ca $1000 \mathrm{~m}$ in the offshore Canterbury Basin, New Zealand [35] (Figure 1). Interpretation of the diverse parts that together comprise the architecture of buried volcanic systems can provide valuable insights into how these ancient volcanoes formed and evolved in time and space $[15,36]$. Understanding the complete architecture of volcanic systems is beneficial for estimating the potential of buried and modern volcanoes to host natural resources such as petroleum, geothermal energy and minerals [4, 37, 39, 40]. Insights of this work into the exploration of geoenergy resources such as oil, gas and geothermal heat is the topic of further work to be publish as a separate paper.

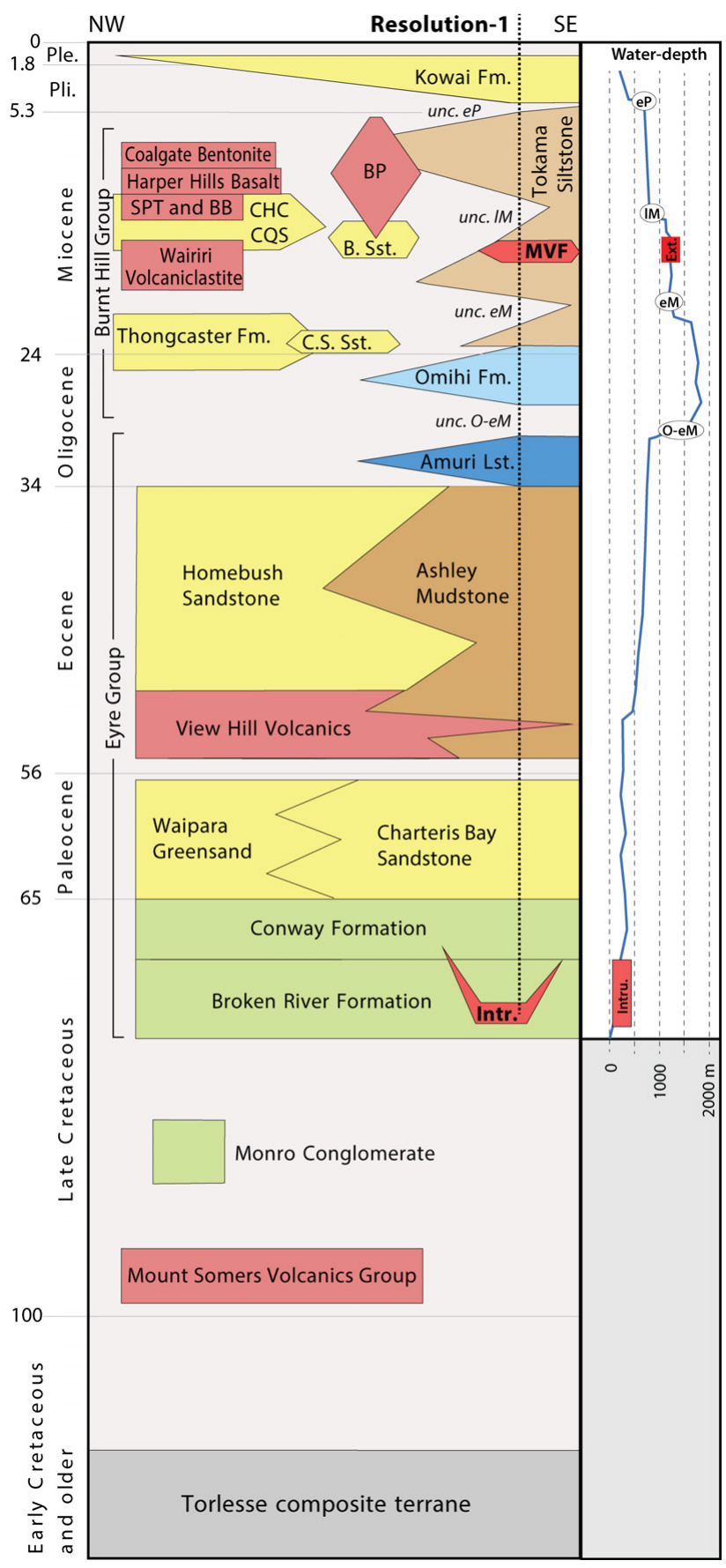

Figure 2: Simplified Cretaceous and Cenozoic chronostratigraphic chart of the northern Canterbury Basin. Abbreviations are: middle Miocene monzogabbro intrusion (Intr.), Curiosity Shop Sandstone (C.S. Sst.), Bradley Sandstone (B. Sst.), Chalk Quarry Sandstone (CQS), Chalk Hill Clay (CHC), Maahunui Volcanic Field (MVF), Banks Peninsula volcanics (BP), Sandpit Tuff (SPT) and Bluff Basalt (BB). Age of unconformities in the Resolution-1 well are: Oligocene-early Miocene (O-eM), early Miocene (eM), late Miocene (IM) and early Pliocene (eP). Modified from [35] after $[43,46,136,137]$. In the right side we show the water-depth variation from Cretaceous to Pleistocene at the location of the Resolution-1 borehole. 


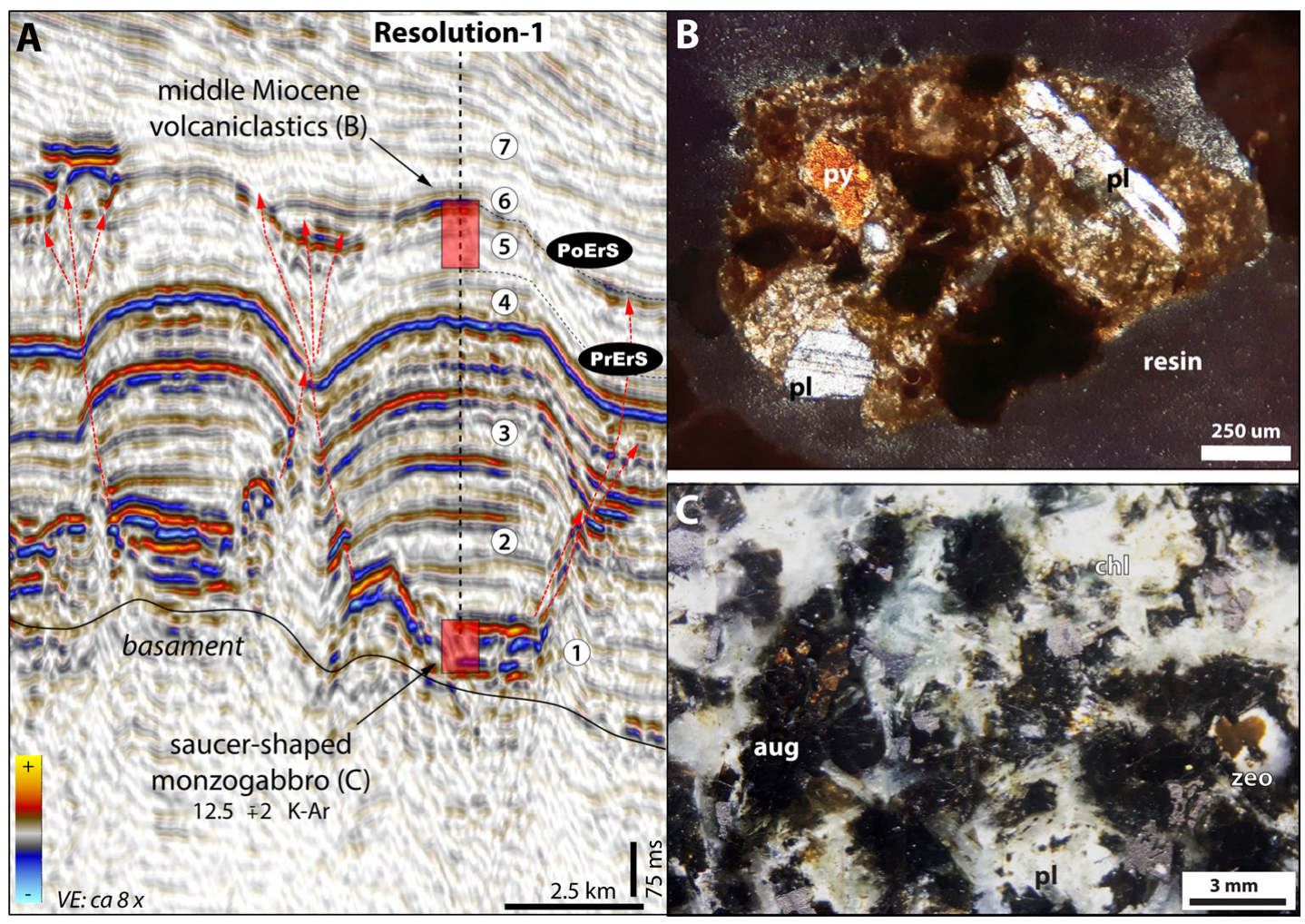

Figure 3: (A) seismic line at the location of the Resolution-1 borehole showing a saucer-shaped sill in 2D section. Red dashed lines indicate potential up-sequence pathways for magma and hydrothermal fluid migration. Vertical scale is shown in milliseconds (ms). Numbers in circles are the paleo-environmental settings at the location of the Resolution-1 borehole. (1) paralic to neritic, (2) neritic to upper bathyal, (3) lower bathyal, (4) deep-lower bathyal, (5) lower bathyal, (6), mid bathyal, (7) uppermost bathyal. PrErs is the pre-eruptive surface and PoErS is the post-eruptive surface. Red square indicates the time that the Maahunui Volcanic Field was active. (B) Thin sections in crosspolarized light showing volcaniclastic fragments from Resoltuion-1 with microporphyritic and vitrophyric textures. Minerals are pyroxene (py), plagioclase ( $\mathrm{pl}$ ) and palagonite (brown colours). (C) Medium-grained monzogabbro showing plagioclase (pl), pyroxene (aug), chlorite (chl) and zeolite (zeo). Modified from [35, 38].

\section{Geological Background}

The Maahunui Volcanic System (MVS) comprises a cluster of at least 31 middle Miocene small-volume (ca $1 \mathrm{~km}^{3}$ ) volcanoes currently buried by ca $1000 \mathrm{~m}$ of sedimentary strata in the Canterbury Basin, New Zealand [40] (Figure 1 and 2). During the Cenozoic, the Canterbury Basin experienced widespread and long-lived intraplate volcanism semi-continuously [41-50] Products of this magmatism are primarily mafic in composition and resulted in the formation of both monogenetic volcanic fields such as the Waiareka/Deborah and Waipiata Volcanic Fields [44, 47], and large polygenetic volcanic complexes like those of Banks and Otago Peninsulas [45, 51]. In the offshore Canterbury Basin, several late Cretaceous to Pleistocene buried volcanoes and intrusive bodies have been mapped based on interpretation of $2 \mathrm{D}$ and 3D seismic reflection datasets [46, 52-54]. Despite a number of exploration boreholes that have recovered representative rocks of these buried off- shore volcanoes, there has been few detailed studies of their eruptive histories.

Volcanoes of the MVS were imaged by high-quality 2D seismic lines and drilled by the Resolution-1 petroleum exploration well (Figure 1), which recovered a monzogabbro intrusion and correlative middle Miocene volcaniclastic rocks [41] (Figure 3). Volcanism in the MVS is estimated to have been active from 12.7 to $11.5 \mathrm{Ma}$ [35]. The products of this volcanic activity are observed over an area of ca 1,520 $\mathrm{km}^{2}$, located $40 \mathrm{~km} \mathrm{SW}$ and offshore of Banks Peninsula (Figure 1). Eruptions in the MVS were short-lived and entirely submarine (500 to $1500 \mathrm{~m}$ in depth), controlled by a plumbing system that fed magma to disperse eruptive centres, which is common characteristic of monogenetic volcanic fields [38]. The magmatic products of MVS melts are primarily basaltic-alkaline in composition, and mainly produced the deep-water equivalents of tuff cones and maar-diatreme volcanoes [35, 38] (Figure 3). After volcanism ceased, volcanoes located in a bathyal setting were 


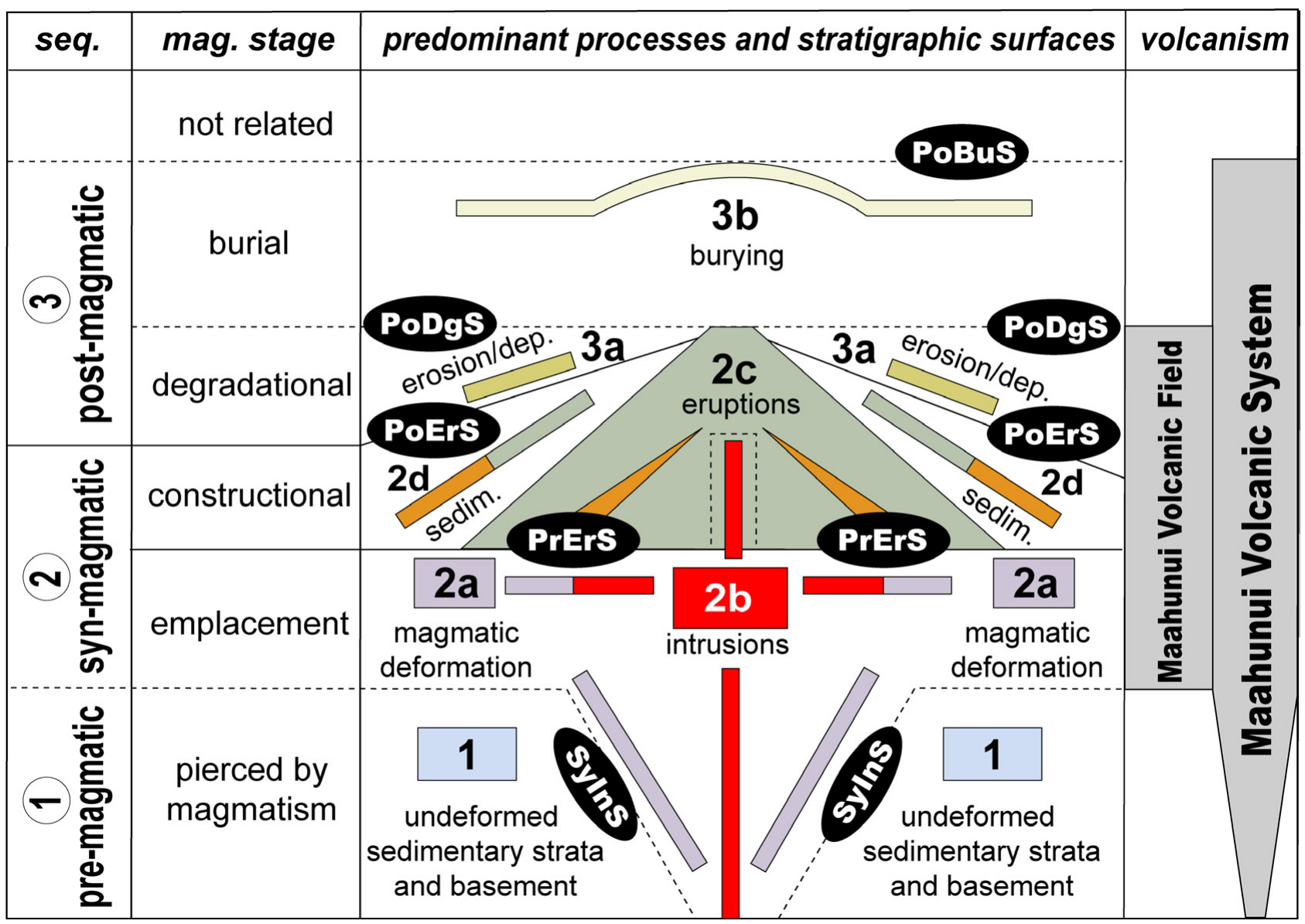

Figure 4: Conceptual representation of the magmatic sequences and stages (left), dominant geological processes, stratigraphic surfaces (centre), and boundaries of the MVF and MFS (right).

buried and well preserved in the Canterbury Basin sedimentary strata, while higher volcanoes (> $200 \mathrm{~m}$ ) located in a neritic setting were emergent at the paleo sea-surface and thus have had their tops flattened by erosional processes [38]. These particular eruptive styles and differential erosion produced a variety of architectural elements related with the evolution of the MVS, which is the topic of the present paper.

\section{Dataset, Methods and Concepts}

In this study, we used more than 40,000 km of highquality 2D seismic lines tied to six boreholes drilled in the northern Canterbury Basin (Leeston-1, Clipper-1, Ealing-1, Resolution-1; Charteris Bay-1 and -2) to interpret how diverse architectural elements vary in time and space in the MVS (Figure 1). We contrast the observations from this dataset with insights from tens of outcropping, submerged, and buried volcanic systems imaged by 3D seismic surveys from both New Zealand sedimentary basins and globally. The compiled datasets are complementary, providing information about the rock-types, eruptive styles, magmasediment interactions, volcanic morphologies, and volcanic architecture within the basin strata. The available information helps us to build a comprehensive volcanostratigraphic framework (Figure 4) showing the locations of individual, or sets of, cogenetic volcanic and sedimentary architectural elements, as well as explaining the complete architecture of the MVS from emplacement to burial in the Canterbury Basin.

\subsection{Magmatic-stratigraphic framework of buried volcanic systems}

The volcanic system concept applied in this work is an extension of the igneous boundaries of the Maahunui Volcanic Field (MVF) presented in [35, 38, 40]. In addition to the intrusive and extrusive parts of the MVF, the MVS includes two supplementary parts: i) the sedimentary strata 
Table 1: Main characteristics of the stratigraphic surfaces that bound distinctive magmatic sequences and stages in the MVS.

\begin{tabular}{|c|c|c|c|c|c|}
\hline $\begin{array}{l}\text { Stratigraphic } \\
\text { Surface }\end{array}$ & Abbr. & Contact relationship & Defined by & Relative time & $\begin{array}{l}\text { Typical architectural } \\
\text { elements }\end{array}$ \\
\hline $\begin{array}{l}\text { Post-burial } \\
\text { surface }\end{array}$ & PoBuS & $\begin{array}{l}\text { Conformable to both } \\
\text { degradational and } \\
\text { constructional stages. }\end{array}$ & $\begin{array}{l}\text { Arbitrary surface that } \\
\text { limits the relative } \\
\text { influence of MVS in the } \\
\text { basin architecture. }\end{array}$ & $\begin{array}{l}\text { Can be synchronous or } \\
\text { strongly diachronous ( }> \\
5 \mathrm{Ma} \text { ) from diverse } \\
\text { eruptive centres. }\end{array}$ & $\begin{array}{l}\text { Top of the burial dome } \\
\text { and associated } \\
\text { seamount-edge fans. }\end{array}$ \\
\hline $\begin{array}{l}\text { Post- } \\
\text { degradational } \\
\text { surface }\end{array}$ & PoDgS & $\begin{array}{l}\text { Erosional into } \\
\text { constructional stage. } \\
\text { Laterally conformable } \\
\text { within burial stage. }\end{array}$ & $\begin{array}{l}\text { Arbitrary surface } \\
\text { relative to one or more } \\
\text { eruption centres, for } \\
\text { which the rate of burial } \\
\text { exceeds the rate of } \\
\text { degradation. }\end{array}$ & $\begin{array}{l}\text { Can be synchronous or } \\
\text { diachronous from } \\
\text { diverse eruptive centres } \\
(>1 \mathrm{Ma} \text { and }<2 \mathrm{Ma}) \text {. }\end{array}$ & $\begin{array}{c}\text { Epiclastic debris } \\
\text { deposits proximal to } \\
\text { volcanic edifices and } \\
\text { distal non-volcanogenic } \\
\text { sedimentary deposits. } \\
\text { Canyons and gullies, } \\
\text { inter-cone plains. }\end{array}$ \\
\hline $\begin{array}{l}\text { Post-eruptive } \\
\text { surface }\end{array}$ & PoErS & $\begin{array}{l}\text { Overlies the } \\
\text { constructional stage. } \\
\text { Amalgamated or parallel } \\
\text { with the PrErS for } \\
\text { increasing distance } \\
\text { from eruptive centres. }\end{array}$ & $\begin{array}{l}\text { Younger eruptive event } \\
\text { in MVS. }\end{array}$ & $\begin{array}{c}\text { Minor diachronous from } \\
\text { diverse eruptive centres. } \\
\text { Usually < } 1 \text { Ma. Max } 1.5 \\
\text { Ma. }\end{array}$ & $\begin{array}{l}\text { Epiclastic debris } \\
\text { deposits proximal to } \\
\text { volcanic edifices and } \\
\text { distal non-volcanogenic } \\
\text { sedimentary deposits } \\
\text { that overlay PoErS. }\end{array}$ \\
\hline $\begin{array}{l}\text { Pre-eruptive } \\
\text { surface }\end{array}$ & PrErS & $\begin{array}{l}\text { Overlies the } \\
\text { pre-magmatic sequence } \\
\text { and the emplacement } \\
\text { stage. }\end{array}$ & $\begin{array}{l}\text { Older eruptive event in } \\
\text { MVS. }\end{array}$ & $\begin{array}{c}\text { Minor diachronous from } \\
\text { diverse eruptive centres. } \\
\text { Usually< } 1 \text { Ma. Max } 1.5 \\
\text { Ma. }\end{array}$ & $\begin{array}{c}\text { Primary eruptive and } \\
\text { eruption-related } \\
\text { deposits that overlay } \\
\text { PrErS. }\end{array}$ \\
\hline $\begin{array}{l}\text { Syn-intrusive } \\
\text { surface }\end{array}$ & SylnS & $\begin{array}{l}\text { Cross-cut the } \\
\text { pre-magmatic sequence. } \\
\text { Eventual minor } \\
\text { cross-cutting into the } \\
\text { constructional stage } \\
\text { near eruptive centres or } \\
\text { at very shallow } \\
\text { intrusions. }\end{array}$ & $\begin{array}{l}\text { Presence of intrusive } \\
\text { bodies and strata } \\
\text { deformed by } \\
\text { magmatism. }\end{array}$ & $\begin{array}{c}\text { Minor diachronous from } \\
\text { diverse eruptive centres. } \\
\text { Usually< } 1 \text { Ma. Max } 1.5 \\
\text { Ma. }\end{array}$ & $\begin{array}{l}\text { Dikes, sills, laccoliths, } \\
\text { stocks, saucer-shaped } \\
\text { sills, and disrupted } \\
\text { blocks. }\end{array}$ \\
\hline
\end{tabular}

deformed by the MVF plumbing system, and ii) the posteruptive sedimentary deposits impacted by the presence of the MVF volcanoes (Figure 4).

Standard methods for analysing the stratigraphic record of sedimentary basins are typically based on observations of stratigraphic surfaces that represent shifts in the local architecture of the basin [55-58]. Similarly, the magmatic-stratigraphy framework of MVS was also built following sequence stratigraphic principles such as stratal reflection relationships and depositional trends within seismic facies [59, 60]. In sedimentary basins impacted by igneous activity, these stratigraphic trends typically mark the boundaries between diverse magmatic events $[2,3,6]$. In this study, we use a model-independent sequence stratigraphic methodology $[60,61]$ to identify the bounding surfaces that mark important shifts in basin stratal patterns of the study area and the relationship of these bonding surfaces with the magmatic activity of the MVS.

We subdivide the stratigraphic record of the MVS into three first-order intervals (i.e. pre, syn and post-magmatic sequences; Figure 4). The pre-magmatic sequence pre- dates magmatism and is cross-cut by the MVS plumbing system. The syn-magmatic sequence comprises both intrusive and extrusive parts of the volcano. The post-magmatic sequence is characterised by degradation and burial of the volcanic structures after magmatism has ceased. These first-order sequences were sub-divided into second-order magmatic stages (i.e. emplacement, construction, degradation and burial stages), depending on the dominant igneous or sedimentary processes that control the architecture of the north Canterbury Basin at each magmatic stage (Figure 4).

Definition of the primary magmatic-stratigraphic surfaces of the MVS follows well-established terminology such as, pre-eruptive surface (PrErS) and post-eruptive surface (PoErS). In other cases, we introduce new terminology such as syn-intrusive surface (SyInS), post-degradational surface (PoDgS) and post-burial surface (PoBuS). Further work is necessary to understand how the stratigraphic units of buried volcanic systems correlate with general models of volcanic stratigraphy proposed from outcropping and modern volcanoes [22, 62-67]. Table 1 shows the 
characteristics of the stratigraphic surfaces and their correlative magmatic sequences and stages in the MVS.

\subsection{Volcanic and Sedimentary Architectural Elements}

Each of the MVS magmatic stages is characterised by a network of genetically related fundamental building blocks (i.e. architectural elements), formed by interactions between intrusions, eruptions, and sedimentation. The concept of architectural elements was introduced by [68] and extended [69] to describe sets of genetically related rock associations that form the fundamental building blocks of fluvial systems. This concept is now widely used in most clastic sedimentary systems [70-77], and has also been successfully introduced in carbonate systems (e.g. [78-80]. In this study, the architectural element concept is applied to document the fundamental blocks of volcanic systems buried in sedimentary basins [6].

Interpretation of the architectural elements of the MVS was primarily achieved by observations from 2D seismic lines that image the volcanic field, and follows two approaches: one with complementary information from well data, the second without well data (Figure 5). In both approaches, we initially characterised the $2 \mathrm{D}$ aspects of seismic anomalies that correspond to igneous rocks buried in the study area. This characterisation was based on numerous criteria such as, the morphology of igneous seismic anomalies, their internal and external seismic facies, and their stratal relationship with enclosing strata. Additional criteria includes the type of stratigraphic surface that bounds the seismic anomaly from adjacent strata, in other words, the stratigraphic position of the anomaly in the volcano-stratigraphic framework (Figure 4).

The results from 2D characterisation were compared with observations from outcropping and buried analogues elsewhere, searching for insights into possible 3D architectures that may correspond to the seismic anomalies identified in 2D seismic data. The final interpretations produced similar results whether the seismic data was correlated to drillholes or not. However, rock samples from drill holes are advantageous because they can provide physical evidence of the subsurface rocks imaged indirectly by remote sensing techniques (Figure 5). The utility of 2D seismic reflection methods are limited by their resolution and line spacing, which in the study area are tens of meters vertically and $<1 \mathrm{~km}$ laterally.

\section{Stratigraphy of Architectural Elements of Maahunui Volcanic System}

We have identified 25 architectural elements that together comprise the complete architecture of the MVS (Figure 6). In this section we present a detailed characterisation of each architectural element according to their stratigraphic position in the pre-, syn- and post-magmatic sequences. Architectural elements formed during the pre-magmatic sequence and undeformed by magmatic processes are not described in this work.

\subsection{Syn-Magmatic Sequence}

The syn-magmatic sequence of the MVS comprises the endogenous and exogenous parts of the volcanic system. This sequence is characterised by rock units formed during the emplacement of intrusive bodies, eruptions, and time-equivalent sedimentation and, also, encompasses pre-magmatic strata deformed by magmatic activity (Figure 6).

\subsubsection{Syn-intrusive architectural elements: plumbing system and magmatic deformation}

The syn-intrusive architectural elements of the MVS were formed in association with the emplacement of a shallow $(<3 \mathrm{~km})$ magmatic plumbing system that intruded and deformed the Cretaceous to Miocene sedimentary strata of the northern Canterbury Basin (Figures 1 and 6). Synintrusive architectural elements of the MVS comprise sills, saucer-shaped sills, dikes, small stocks and laccoliths. These syn-intrusive elements typically occur below the PrErS surface, however, some shallow intrusions cross-cut and emplaced within syn-eruptive deposits near eruptive centres (Figures 6, 7 and 8). Together, the syn-intrusive architectural elements display characteristic geometries and relationships with enclosing strata, which are discussed in the next section. Table 2 shows the main characteristics of the syn-intrusive architectural elements of the MVS.

\section{MVS plumbing-types}

We broadly characterise the shallow plumbing system of the MVS into five plumbing-types (Figures 6, 7 and 8), 

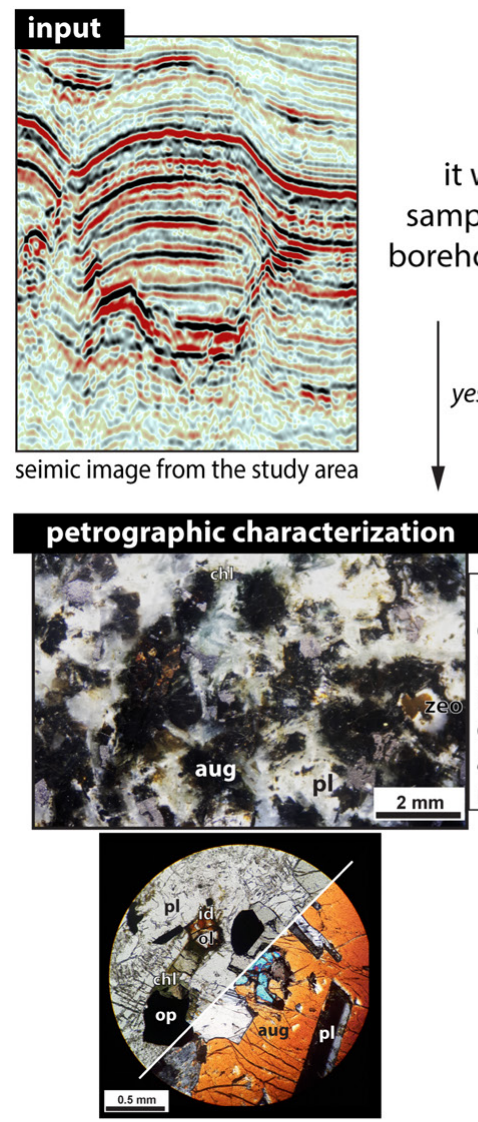

it was sampled by borehole well?
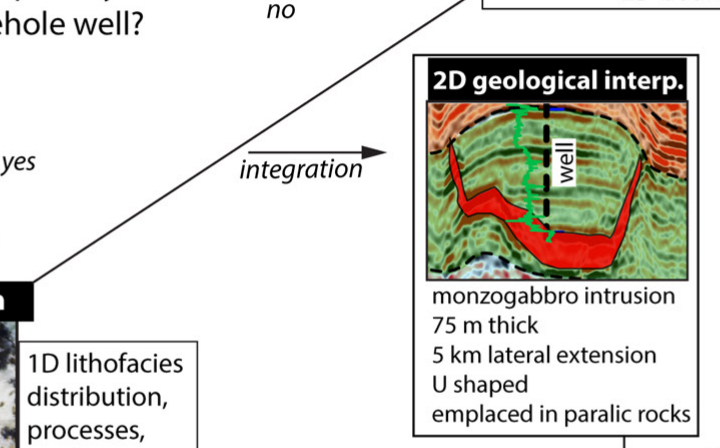

there is $3 D$ seismic data available or it is

possible to map 3D geobodies from the 2D dataset?
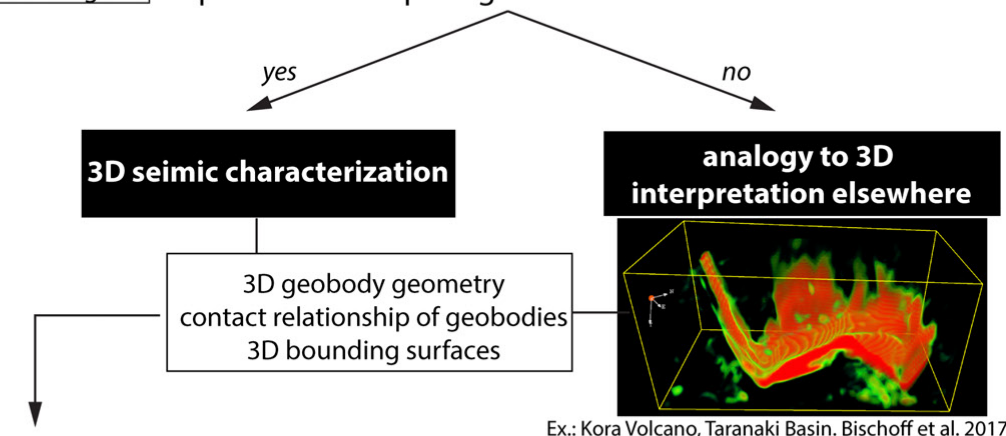

analogy to world-wide outcroping systems

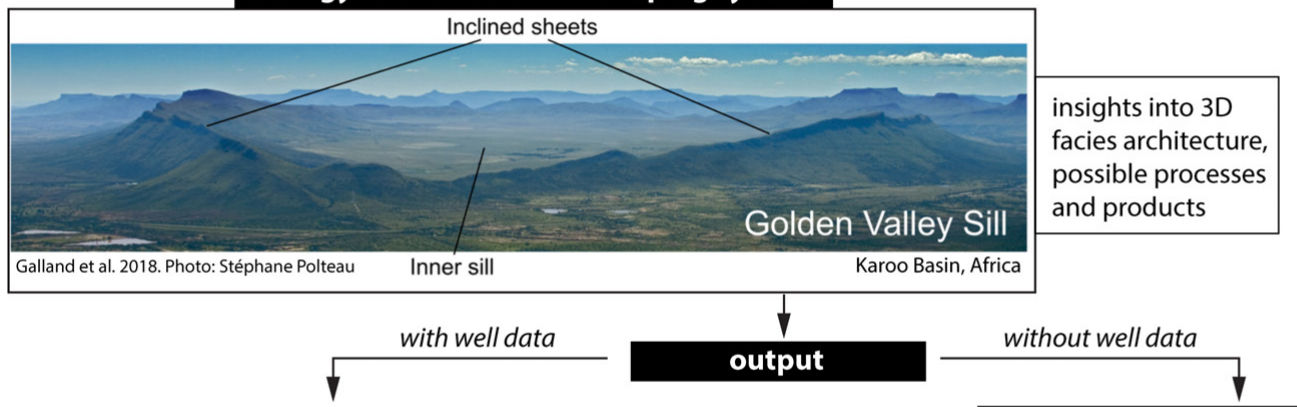

tested element

Saucer-shaped intrusion of basaltic composition and middle Miocene age, varying in size from tens of meters thick to kilometres wide, bounded by sharp contacts between igneous and sedimentary rocks, which are commonly observed in sedimentary basins pierced by hypabyssal intrusions.

\section{D seimic characterization}

reflectors terminations

2D morphology of reflectors relationship to surrounding strata $2 \mathrm{D}$ bounding surfaces

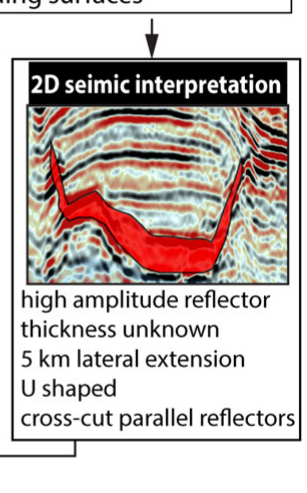




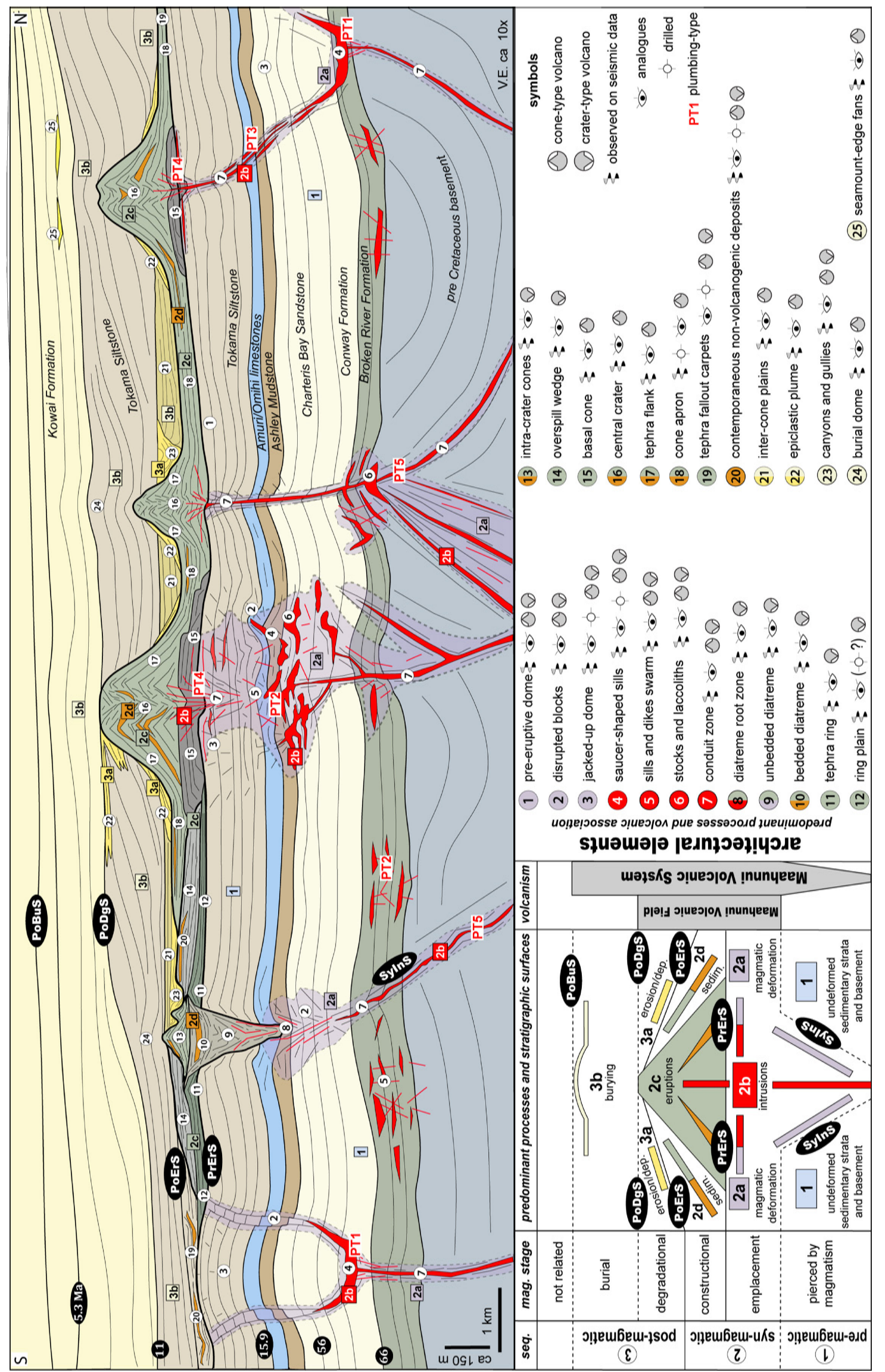

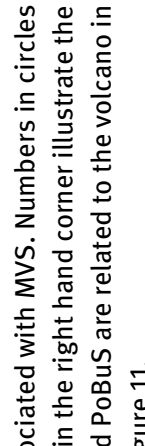

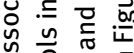

政品

ङ है है ड

过

흘

它 远

暂焉

응 든 을

它觊

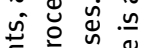

屯을

造

뜬 $\bar{\xi}$ 을

造

它

品要

ธิ

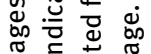

ज

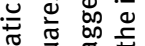

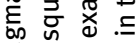

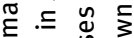

ปे

造 है 흘 ज文资

항

它㐫选

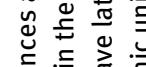

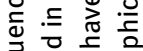

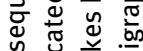

.

䏠

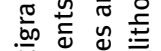

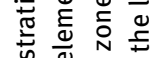

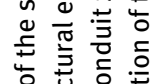

엉

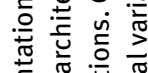

造

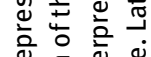

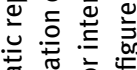

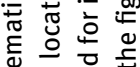

莺焉总

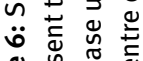

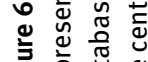

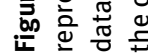



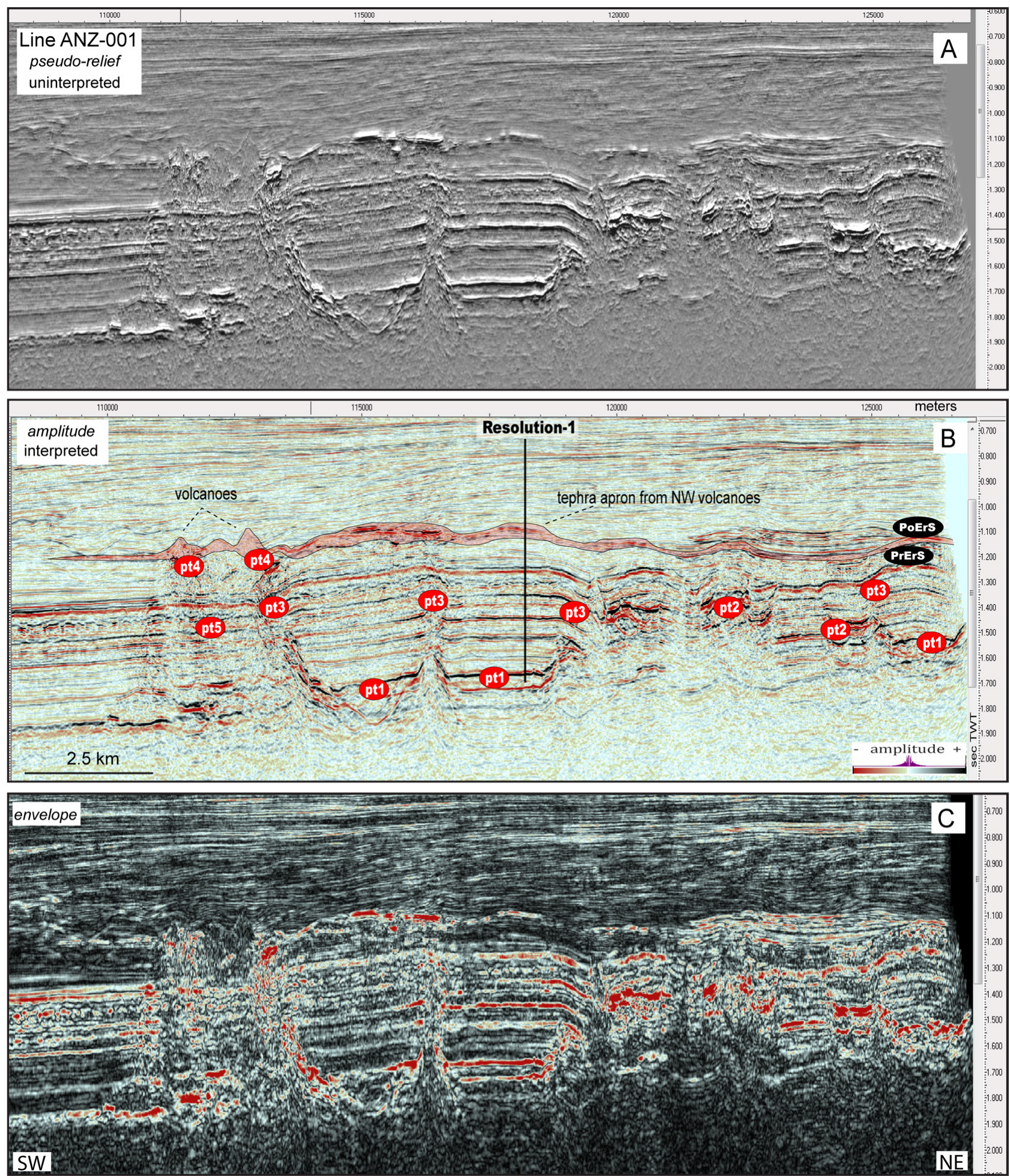

Figure 7: 2D seismic reflection lines showing the locations and geometries of the five plumbing-types observed in the MVS. Images A, B and $C$ show the same line ANZ-001 which display the seismic attributes pseudo-relief (A), amplitude (B) and envelope (C). Note the systematic vertical distribution from type-1 (deeper) to type-4 (shallower) intrusive elements. Type- 5 differs from the other types in that it represents a deep source-to-surface feeder system. 
Table 2: Main characteristics of the syn-intrusive architectural elements in the MVS.

\begin{tabular}{|c|c|c|c|c|c|}
\hline Element & Association & Seismic facies & Bounding surfaces & Geometry & Indicative process \\
\hline Sills & $\begin{array}{l}\text { Plumbing-types } \\
2 \text { and } 4 .\end{array}$ & $\begin{array}{c}\text { Anomalous single, high } \\
\text { amplitude } \\
\text { semi-continuous } \\
\text { horizontal reflector. }\end{array}$ & $\begin{array}{l}\text { Sharp contact between } \\
\text { single high amplitude } \\
\text { reflector and external } \\
\text { bedded seismic facies. }\end{array}$ & $\begin{array}{c}\text { Tabular } \\
\text { horizontal to } \\
\text { sub-horizontal. }\end{array}$ & $\begin{array}{c}\text { Dense rock body } \\
\text { emplaced parallel within } \\
\text { enclosing strata. }\end{array}$ \\
\hline $\begin{array}{l}\text { Saucer- } \\
\text { shaped } \\
\text { sills }\end{array}$ & $\begin{array}{l}\text { Plumbing-type } 1 \\
\text { and } 2 .\end{array}$ & $\begin{array}{l}\text { Typically single high } \\
\text { amplitude, } \\
\text { semi-continuous, } \\
\text { horizontal to inclined } \\
\text { reflector. }\end{array}$ & $\begin{array}{l}\text { Sharp contact between } \\
\text { single high amplitude } \\
\text { reflector and external } \\
\text { bedded seismic facies. }\end{array}$ & Saucer-like. & $\begin{array}{l}\text { Dense rock body } \\
\text { emplaced parallel within } \\
\text { enclosing strata. Jack-up, } \\
\text { brittle deformation and } \\
\text { body cross-cutting } \\
\text { enclosing strata. }\end{array}$ \\
\hline Dikes & $\begin{array}{l}\text { Plumbing-types } \\
3,4 \text { and } 5 .\end{array}$ & $\begin{array}{l}\text { Single, narrow, vertical to } \\
\text { sub-vertical transparent } \\
\text { (i.e. reflector-free) } \\
\text { discontinuities in bedded } \\
\text { strata. }\end{array}$ & $\begin{array}{l}\text { Sharp contact between } \\
\text { sub-vertical transparent } \\
\text { discontinuities and } \\
\text { external bedded seismic } \\
\text { facies. }\end{array}$ & $\begin{array}{l}\text { Tabular vertical } \\
\text { to sub-vertical. } \\
\text { Typically } \\
\text { seismically } \\
\text { unresolved. }\end{array}$ & $\begin{array}{l}\text { Rock body cross-cutting } \\
\text { enclosing strata. }\end{array}$ \\
\hline $\begin{array}{l}\text { Dikes-and- } \\
\text { sills swarm }\end{array}$ & $\begin{array}{l}\text { Plumbing-types } \\
2,3 \text { and } 4 .\end{array}$ & $\begin{array}{c}\text { Multiple high amplitude, } \\
\text { discontinuous, } \\
\text { horizontal to steeply } \\
\text { inclined reflectors in } \\
\text { chaotic configuration. }\end{array}$ & $\begin{array}{l}\text { Sharp contacts between } \\
\text { multiple, chaotic, high } \\
\text { amplitude reflectors and } \\
\text { external bedded seismic } \\
\text { facies. }\end{array}$ & $\begin{array}{l}\text { Complex, } \\
\text { chaotic. }\end{array}$ & $\begin{array}{c}\text { Multiple rock bodies } \\
\text { cross-cutting and parallel } \\
\text { emplacing within bedded } \\
\text { strata. }\end{array}$ \\
\hline $\begin{array}{l}\text { Stocks and } \\
\text { laccoliths }\end{array}$ & $\begin{array}{l}\text { Plumbing-types } \\
2 \text { and } 3 .\end{array}$ & $\begin{array}{c}\text { Single, thick, high } \\
\text { amplitude, typically } \\
\text { continuous, semi-circular } \\
\text { reflector. }\end{array}$ & $\begin{array}{c}\text { Sharp contacts between } \\
\text { high amplitude reflectors } \\
\text { and external seismic } \\
\text { facies. }\end{array}$ & $\begin{array}{l}\text { Sub-geoidal. Not } \\
\text { always resolved } \\
\text { in seismic data. }\end{array}$ & $\begin{array}{l}\text { Rock body cross-cutting } \\
\text { enclosing strata. }\end{array}$ \\
\hline $\begin{array}{l}\text { Disrupted } \\
\text { blocks }\end{array}$ & $\begin{array}{l}\text { Plumbing-types } \\
1,2,3,4 \text { and } 5 .\end{array}$ & $\begin{array}{c}\text { Multiple narrow, vertical } \\
\text { to sub-vertical } \\
\text { transparent } \\
\text { discontinuities in bedded } \\
\text { strata. }\end{array}$ & $\begin{array}{l}\text { Sharp contact between } \\
\text { sub-vertical transparent } \\
\text { discontinuities and } \\
\text { external bedded seismic } \\
\text { facies. }\end{array}$ & Chaotic. & $\begin{array}{l}\text { Brittle deformation of } \\
\text { bedded strata. }\end{array}$ \\
\hline $\begin{array}{l}\text { Jacked-up } \\
\text { domes }\end{array}$ & $\begin{array}{c}\text { Plumbing-types } \\
1,2 \text {, and } 3 .\end{array}$ & $\begin{array}{l}\text { Bedded strata domed } \\
\text { above typically single } \\
\text { high amplitude, } \\
\text { semi-continuous, } \\
\text { horizontal to inclined } \\
\text { reflector. }\end{array}$ & $\begin{array}{c}\text { Gradational contact } \\
\text { between domed and } \\
\text { parallel bedded seismic } \\
\text { facies. }\end{array}$ & $\begin{array}{l}\text { Downward- } \\
\text { concave } \\
\text { dome. }\end{array}$ & $\begin{array}{l}\text { Strata jacked up above } \\
\text { rock body emplaced } \\
\text { parallel within enclosing } \\
\text { strata. }\end{array}$ \\
\hline
\end{tabular}

based on the geometry, size and depth of the intrusive bodies, and on their relationship with the enclosing sedimentary strata. Each plumbing-type can contain a variety of intrusive bodies such as dikes, sills and stocks, which are individually described later in this section.

Plumbing-type 1 comprises large (up to $5 \mathrm{~km}$ in width and ca $100 \mathrm{~m}$ thick) sills and saucer-shaped intrusions emplaced into the lower Cretaceous-Paleocene sequences of the northern Canterbury Basin (500 to $1000 \mathrm{~m}$ deep at the time of the formation of these intrusions). The relationship of these bodies display an intrusive network with minor branching, and extensive lateral migration of magma, up to $5 \mathrm{~km}$ from the extremities of the saucer-sills (Figures 6, 7 and 8 ).

Plumbing-type 2 is characterized by small $(<1 \mathrm{~km}$ in width and $<100 \mathrm{~m}$ thick), disrupted, parallel, transgres- sive or saucer-shaped intrusions emplaced into Cretaceous to Oligocene strata (Figures 6, 7 and 8). Typically, these bodies show a complex intrusive network, intense lateral and vertical branching, and moderate magma lateral migration (up to $1 \mathrm{~km}$ ).

Plumbing-type 3 displays narrow, steeply inclined and discontinuous conduit zones, located immediately above the tips of the large saucer-shaped intrusions of plumbingtype 1 (Figures 6, 7 and 8). These bodies have a complex intrusive network characterised by intense vertical branching, and little lateral migration of magma $(<200 \mathrm{~m})$.

Plumbing-type 4 comprises shallow (up to $250 \mathrm{~m}$ deep) swarms of narrow, steeply inclined, parallel and transgressive intrusions, located immediately below eruptive vents (Figures 6, 7 and 8). These bodies display a complex intru- 

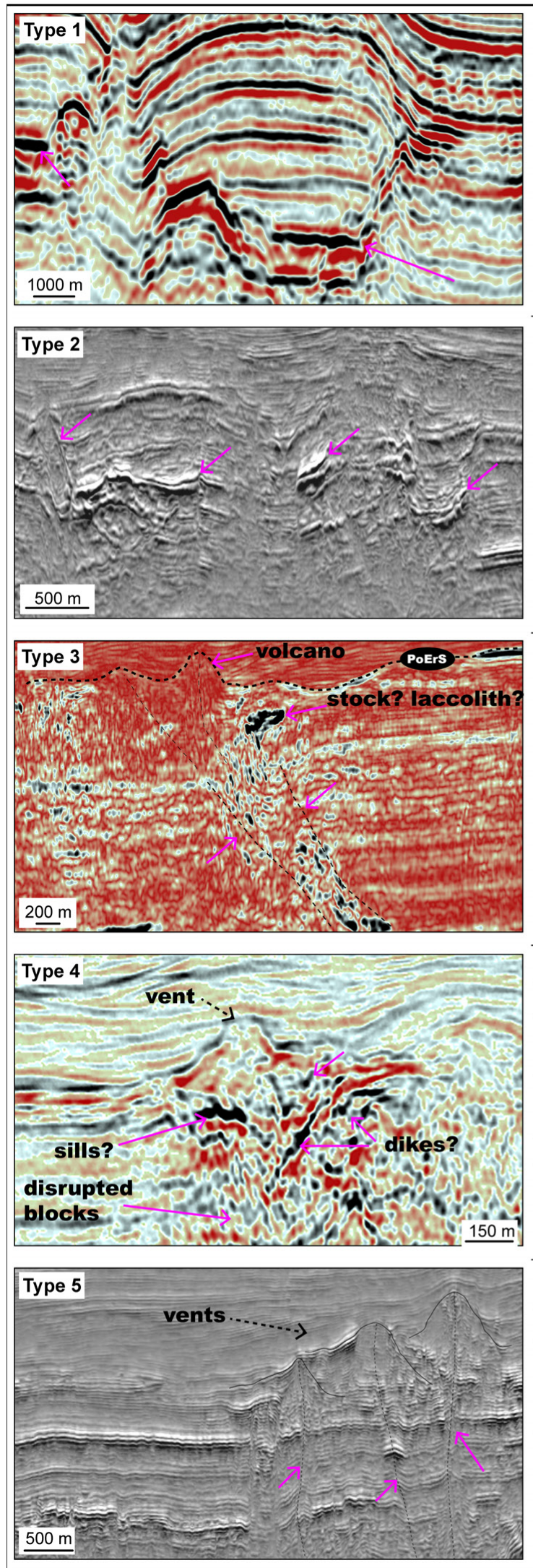

Geometry: Large saucer-shaped with horizontal inner sheet and peripherical inclined sheets.

Size and depth: $1-5 \mathrm{~km}$ in width. Up to $100 \mathrm{~m}$ vertical. 1.3 to $1.8 \mathrm{~s}$ Enclosing strata: Cretaceous-Paleocene. Jacked-up, domed and parallel. Minor deformation above, moderate to intense deformation below and at the tips of inclined sheets.

Network: Simple, minor branching, extensive lateral migration. Association: May or may not be associated to Type-3. Interpretation: Saucer-shaped sills and minor intrusions

Geometry: Small disrupted, parallel, transgressivel, inclined or saucer-shaped.

Size and depth: Up to $1 \mathrm{~km}$ in width. Up to $50 \mathrm{~m}$ vertical. 1.2 to $1.5 \mathrm{~s}$. Enclosing strata: Cretaceous-Oligocene. Intense deformation above and below.

Network: Complex, intense branching, Moderate lateral migration. Association: Not observed.

Interpretation: Sills and dike swarms.

Geometry: Narrow, steeply inclined, tabular, disrupted. Some stock-like also can occurs.

Size and depth: Few hundreds of meters in width. Up to $800 \mathrm{~m}$ vertical. 1.1 to $1.6 \mathrm{~s}$

Enclosing strata: Paleocene-Miocene. Intense deformation above and below.

Network: Complex, intense branching, little lateral migration.

Association: Often above inclined sheet of Type-1 and often connected to eruptive vents.

Interpretation: Dike swarms, magmatic and hydrothermal conduits.

Geometry: Shallow, steeply inclined, tabular, transgressive, disrupted Size and depth: Up to $2 \mathrm{~km}$ in width and $<50 \mathrm{~m}$ thick. 1 to $1.3 \mathrm{~s}$. Enclosing strata: Oligocene-Miocene. Moderate deformation above and below.

Network: Complex, intense branching, little lateral migration.

Association: Often below eruptive vents. Can be located above Type-3 and Type-5.

Interpretation: Shallow sills and dike swarms, and magmatic condutis located at sub-vent zones.

Geometry: Narrow, sub-vertical, continuous.

Size and depth: $<50 \mathrm{~m}$ in width and $>4 \mathrm{~km}$ vertical. 1 to $>3 \mathrm{~s}$.

Enclosing strata: Basement-Miocene. Moderate lateral deformation. Network: Simple, no branching, no lateral migration.

Association: Below eruptive vents and directly connected to depper basement zones. Some cases with Type-4 and Type-2.

Interpretation: Deep source to surface magmatic conduits.

Figure 8: 2D seismic reflection images and characterisation of the five plumbing-types from the MVS. Seismic attributes of the images are: Type-1= amplitude, Type- $2=$ pseudo-relief, Type-3= envelope, Type- $4=$ amplitude and Type-5= pseudo-relief. 

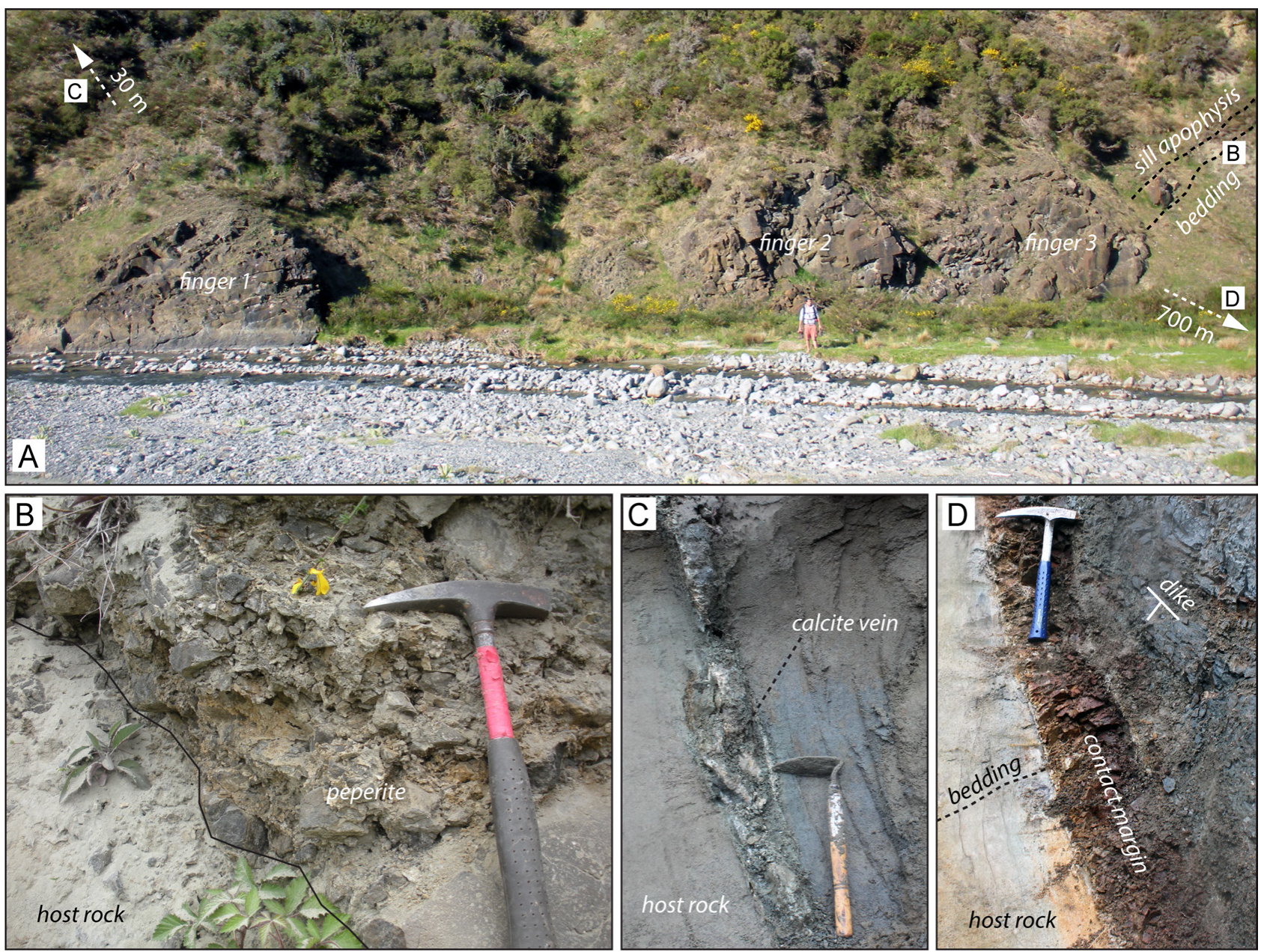

Figure 9: Photographs of potential analogue dikes outcropping in the Canterbury Basin. Intrusions have different patterns and products according to their depth of emplacement. At deeper levels, dikes show sharp contacts and little branching into enclosing sediments (D), while at shallower levels, they show magma finger terminations and a number of thin apophysis with peperitic borders. Thirty meters above the shallower intrusions, calcite veins (C) suggest migration of fluids up-sequence.

sive network with numerous branches, and little lateral migration of magma $(<300 \mathrm{~m})$.

Plumbing-type 5 are narrow ( $<50 \mathrm{~m}$ in width) and steeply inclined conduit zones showing simple intrusive network, little branching, and little lateral migration of magma $(<50 \mathrm{~m})$. These bodies form a single and continuous intrusion zone that cross-cuts the basement fabric and the Cretaceous-Miocene sequences of the northern Canterbury Basin $(>5 \mathrm{~km}$, which is the resolution limit of our dataset). Its upper termination is connected with the root zone of some MVS eruptive vents (Figures 6, 7 and 8).

\section{Sills and saucer-shaped sills}

Sills and saucer-shaped sills are the most common synintrusive architectural element seismically imaged in the
MVS (Figures 3, 5, 6, 7 and 8). In seismic lines, sills and saucer-shaped sills occur between 1.1 and $1.8 \mathrm{sec}$ TWT (ca 500 to $1000 \mathrm{~m}$ at the emplacement time), and often intrude paralic to marine Cretaceous-Paleocene sedimentary strata. Individual or sets of tabular, parallel, transgressive and saucer-shaped sills vary in width from a few hundred meters to $5 \mathrm{~km}$ and ca $100 \mathrm{~m}$ in thick (Figure 3). The presence of intrusions is often associated with disrupted and deformed enclosing sedimentary rocks, demonstrating that magma being emplaced into, or moving through, the sedimentary basin can produce kilometre-scale deformation. Magmatic-related deformation can include folds, jacked-up strata, and both reverse and normal faults (Figures 3 and 7). These interpretations are supported by observations from sedimentary basins elsewhere $[4,6,27,34$, $50,52,81-85]$ and also by laboratory experiments $[36,86]$. 

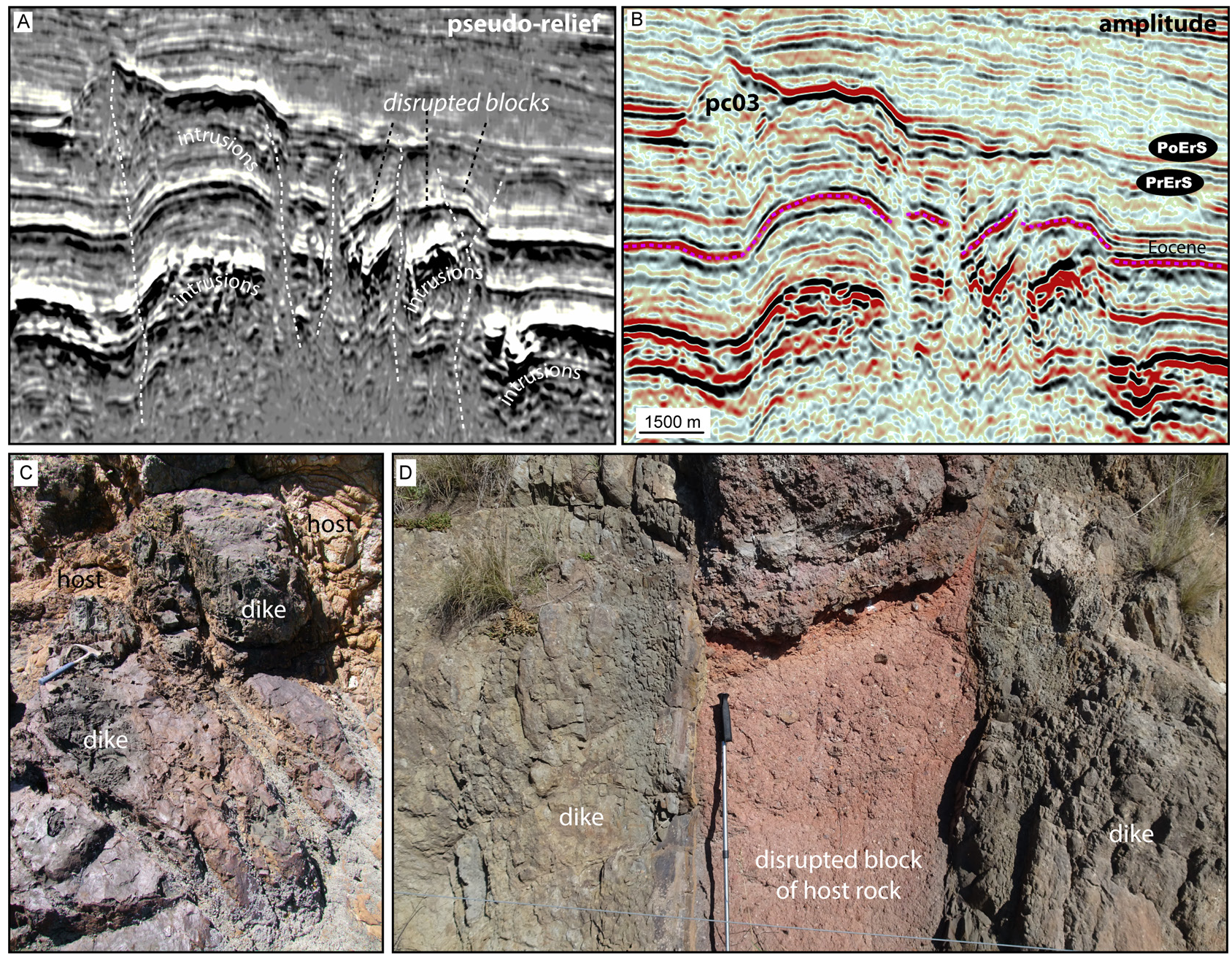

Figure 10: 2D seismic images of disrupted blocks ( $A$ and B), and a possible outcrop scale analogue ( $C$ and $D)$ of this architectural element from Banks Peninsula volcanoes (New Zealand) formed by host pyroclastic deposits cross-cut by multiple dike intrusions.

Petrographic analyses of a Type-1 saucer-shaped sill recovered from the Resolution-1 well provides evidence that this plumbing-type has emplaced and crystallized at relatively shallow depths ca $950 \mathrm{~m}$ in the basin [35] (Figure 3). Seismic images show a direct connection between saucersills and numerous MVS eruptive vents (Figure 7), suggesting that these intrusions likely have served as stationary magma chambers to fed eruptions at the middle Miocene paleo-submarine seabed [38]. This relationship between the emplacement of shallow sills and eruptions was previously described in several locations globally, including buried examples in southern Australian [4, 20], and North Sea sedimentary basins $[34,81,83]$, and also from outcrops such as those from the Hopi Buttes Volcanic Field, USA [27] and the Pannonian Basin, western Hungary [87].

\section{Dikes and magmatic conduits}

Dikes and other potential magmatic conduits are synintrusive architectural elements characterised by vertical and sub-vertical igneous bodies emplaced beneath the preand post-eruptive surfaces (Figures 6, 7 and 8). Due to their steep inclination and narrow lateral thickness, dikes and other magmatic conduits are typically seismically unresolvable. We recognise these bodies by narrow, steeply inclined, tabular high-amplitude reflectors, and by subvertical discontinuities that crosscut pre-magmatic sedimentary strata (Figure 8). In the MVS, these intrusions commonly form complex branching networks, in association with sills and stocks of the plumbing-types 2, 3 and 4, which form similar networks as dikes and sills mapped from 3D seismic reflection data in the Ben Nevis monogenetic volcanic field, for example [34]. In other cases, we observe narrow sub-vertical discontinuities in host strata 


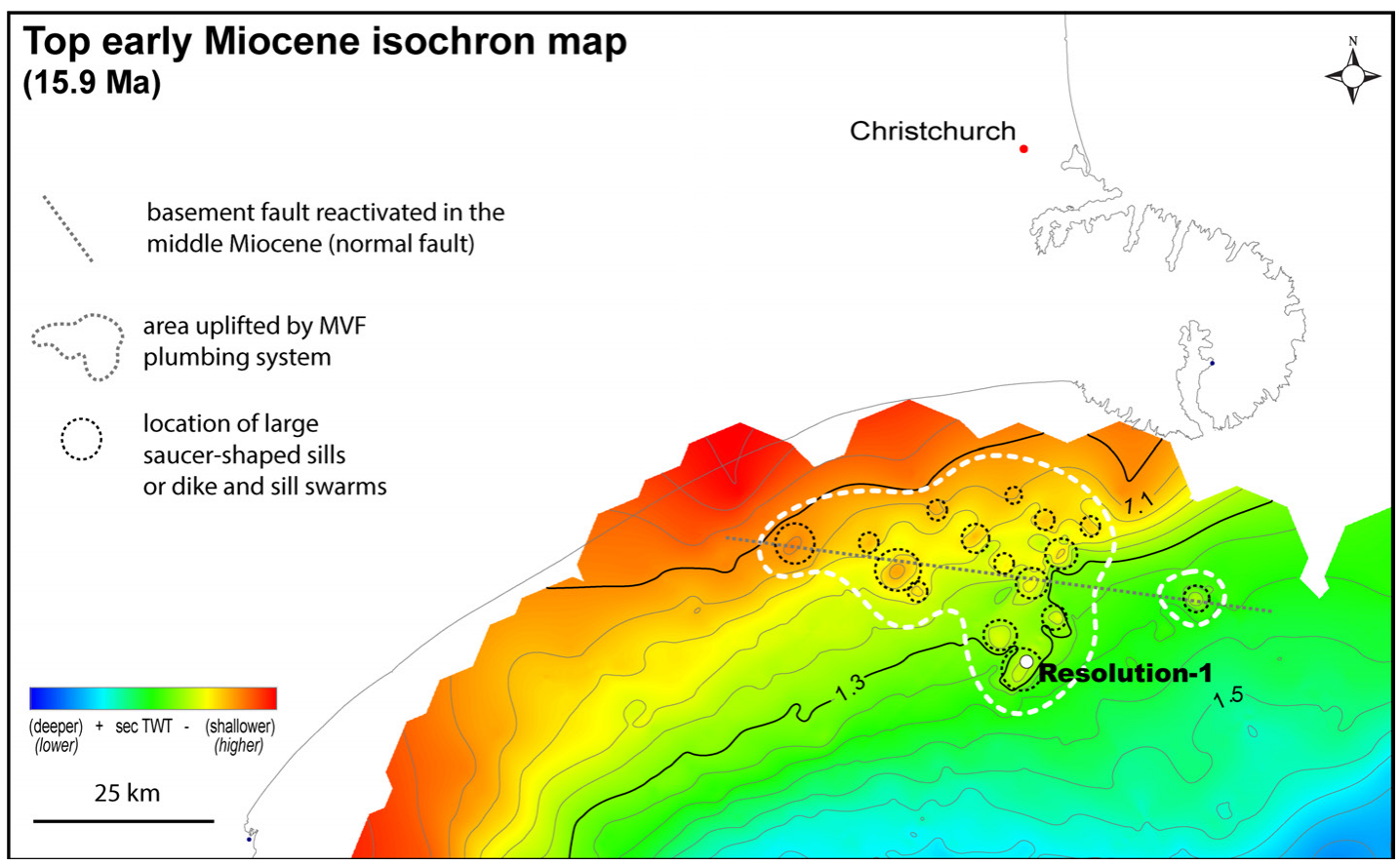

Figure 11: Top early Miocene isochron map of the northern part of Canterbury Basin. The area inside the white dashed line shows uplift with maximum vertical relief of ca $100 \mathrm{~m}$, coincident with the location of large sills and dike and sill swarms of the MVS plumbing system.

that can be tracked from MVS eruptive centres to depths of at least $5 \mathrm{~km}$ (plumbing-type 5). Because these subvertical discontinuities do not show branching or lateral migration, they could potentially represent simpler sourceto-surface magmatic pathways from deeper magma chambers [88].

An analogy for dikes in the MVS is provided by a network of dikes and sills intruding poorly indurated Eocene marine strata in the inland Canterbury Basin (Figure 9). These intrusions show distinctive outcrop patterns that are dependent on their emplacement depths. Deeper level intrusions mainly comprise sub-vertical dikes that show sharp contact relationships with the host sandstones. Shallower intrusions have magma-finger terminations associated with thin $(<1 \mathrm{~m})$ sill apophyses and peperitic borders. Tens of meters up-sequence (and above the intrusions), calcite veins occur cross-cutting sedimentary strata in the absence of hypabyssal rocks, suggesting migration of hydrothermal fluids above these intrusions. Magma finger structures are commonly interpreted to be emplaced within relatively soft sedimentary strata [89], but they have also been described emplaced into craters of maardiatreme volcanoes [90, 91].

\section{Disrupted blocks}

Disrupted blocks are recognised in 2D seismic lines by parallel reflectors with abrupt lateral discontinuities (Figures 8 and 10a and b). Disrupted blocks typically occur below eruptive centres and in association with plumbingtypes 3, 4 and 5, or above and lateral to intrusive bodies of plumbing-types 1 and 2 (Figures 3, 7 and 8). These discontinuous rock masses were likely formed due to fracturing, faulting and forced-folding of host strata, to accommodate deformation caused by the emplacement of intrusive bodies [6, 82, 92]. Another possible mechanism that could form disruptive blocks is the emplacement of multiple closely-spaced intrusions, such as the field example from Banks Peninsula volcanoes shown in Figures 10C and D. Faulting of host sedimentary strata can be an important process for creating pathways for magma and/or fluid migration within basin strata [86, 93].

\section{Jacked-up domes and the MVS pre-eruptive dome}

Jacked-up domes are formed by uplift of pre-eruptive sedimentary strata above large intrusions (Figures 3, 4, 7, 8, 10 and 11). In the study area, these dome structures vary in diameter from 1 to $5 \mathrm{~km}$ and commonly occur above large saucer-shaped sills (plumbing-type 1). Similar dome struc- 
tures are described in magma rich sedimentary basins elsewhere, where they typically form in association with fracture networks containing both normal and reverse faults, which are often observed along the borders of domed structures $[36,81,82,86]$. These fracture networks may provide conduits for magma and fluids as they ascend upsequence (plumbing-type 3 ).

Regionally, the isochron map corresponding to the top of the early Miocene shows a semi-elliptical area of 1,137 $\mathrm{km}^{2}$ that contains several 4-way dipping structures with maximum vertical relief of ca $100 \mathrm{~m}$, located above large saucer-shaped intrusions and/or dikes-and-sills swarms (Figure 11). A possible explanation for this regional uplift (which we refer to as the pre-eruptive dome) is that the large swarms of intrusions emplaced within the sedimentary basin may produce inflation and ground dilatation above the MVS plumbing system, similar to the dome beneath Kora volcano in New Zealand's Taranaki Basin $[6$, 94, 95]. Another possible explanation is that the preeruptive dome could be formed by thermal uplift, representing a smaller-scale version of the Ethiopian and Kenya domes in the Eastern African Rifts [96-98].

\section{Stocks and laccoliths}

Seismic anomalies associated with plumbing-types 2 and 3 have high amplitude reflectors with irregular and concave downward shapes (Figure 8). These anomalies cross-cut deformed enclosing strata, typically producing a domedshaped geometry above these intrusions. These bodies have been interpreted to represent small $(<200 \mathrm{~m})$ stocks that intruded pre-magmatic sedimentary sequences. Laccoliths possibly occur in plumbing-types 2 and 3 , however, separating them from stocks is not possible due to the kilometre-scale spacing of our seismic lines.

In summary, the plumbing system of the MVS is characterised by a complex network of sills and dikes that deform pre-magmatic sedimentary strata. Many of these intrusions (i.e. large saucer-shaped sills of plumbing-type 1) served as stationary shallow $(<1 \mathrm{~km})$ magmatic chambers that fed eruptions at the middle Miocene seabed. In other examples, a deeper source-to-surface system (plumbingtype 5) is likely to have fed some of the MVF volcanoes. Interpretation of the MVS plumbing system suggests that a significant volume of magma (ca $50 \mathrm{~km}^{3}$ ) was emplaced within the sedimentary strata of the basin, with a much smaller volume (ca $20 \mathrm{~km}^{3}$ ) reaching the paleoseabed [38].

\subsubsection{Syn-eruptive architectural elements: eruptive, eruption-related and contemporaneous non-volcanogenic sedimentary deposits}

Syn-eruptive architectural elements are cogenetic sets of eruptive, eruption-related and time-equivalent nonvolcanogenic sedimentary rock units formed during the active constructional stage of the MVS (Figure 6). During the constructional stage, the architecture of the volcanoes in the MVS was mainly controlled by interactions between internally (i.e. magma composition, pressure and magma ascent rate), and externally (i.e. interaction with water and organic rich host rocks, soft or hard country rock, and the presence of pre-existing structures), driven mechanisms of fragmentation, dispersal and volcanic edifice growth [35, 38]. These processes controlling the morphology and architecture of volcanoes are commonly observed in active volcanoes and interpreted from ancient volcanic systems in outcrop [21, 25, 99, 100].

Two main volcano-type morphologies have been observed in the MVS seismic data: (i) crater-type and (ii) conetype volcanoes. Each of these volcano-types contains distinctive combinations of cogenetic sets of syn-eruptive architectural elements at different scales, although some elements occur in both volcano-types (e.g. tephra fallout carpets). We have observed that the seismic morphology of these buried volcanoes is similar to subaerial and submarine monogenetic volcanoes well documented in the literature (e.g. [20, 21, 25, 28, 99, 101-105] (Figures 12 to 19). These similarities assist our interpretations and provide information to construct a comprehensive time-space framework showing the distribution of architectural elements for each volcano-type.

\section{Crater-type volcanoes:}

Crater-type volcanoes of the MVS are interpreted to represent the deep-water equivalent of maar-diatreme volcanoes. In seismic reflection imagery, crater-type volcanoes are characterised by funnel and basin-like excavations into pre-magmatic sedimentary strata. Reconstructed MVS diatremes vary in diameter from 900 to $1700 \mathrm{~m}$, and are excavated 90 to $230 \mathrm{~m}$ deep into the PrErS [38]. These craters were formed in relatively soft ground, locally corresponding to the bathyal Tokama Siltstone in the upper part, and to the micritic Amuri Limestone and Ashley Mudstone in the root zone (Figures 12 and 13). Basin-like excavations are rare in the MVS and difficult to characterise due to seismic resolution limitations, thus, further descriptions con- 

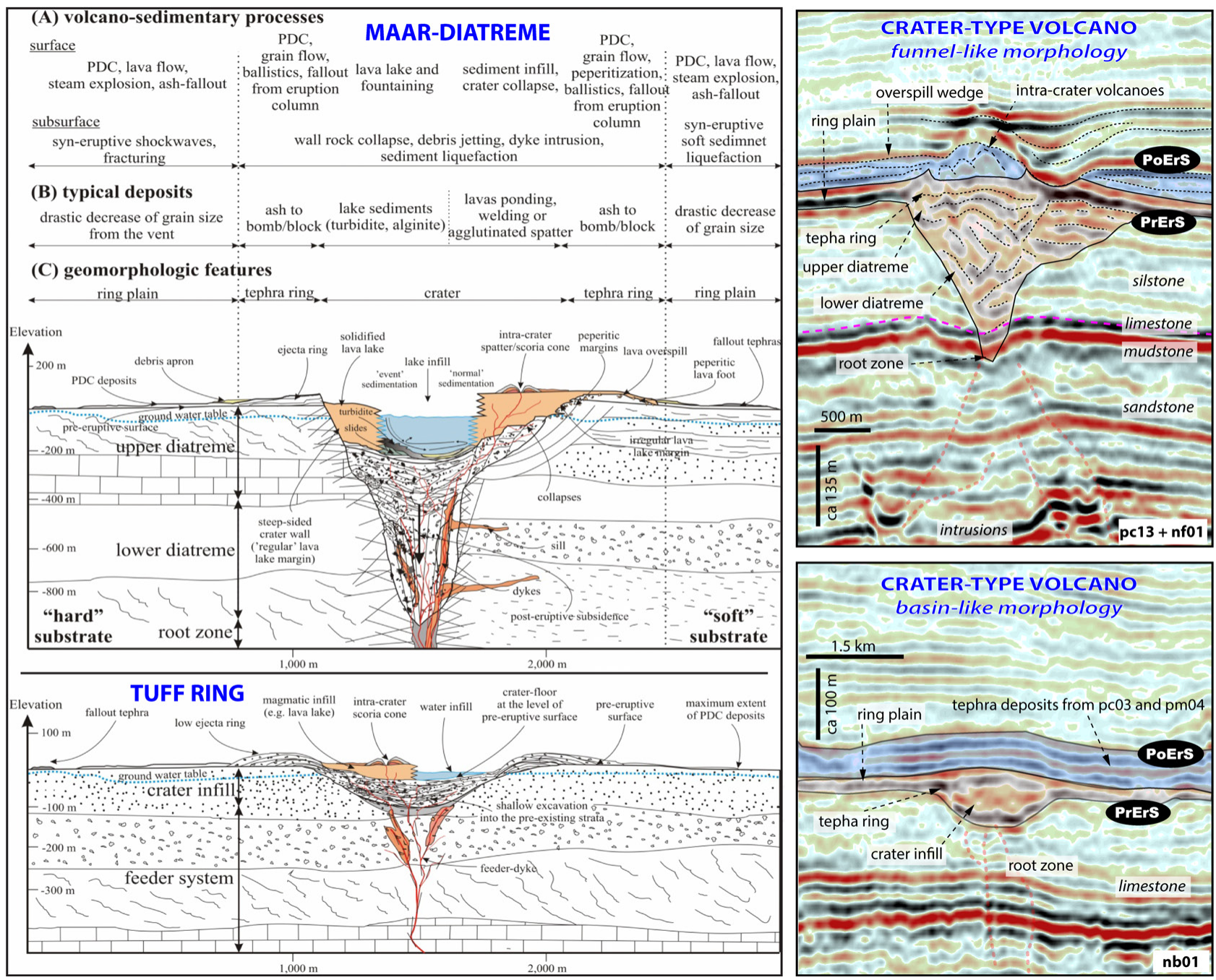

Figure 12: Images on the left show schematic cross-sections through a maar-diatreme and a tuff ring, and their typical volcano-sedimentary processes, deposits and geomorphologic features from [25]. On the right are interpreted 2D seismic lines of the MVS crater-type volcanoes, and their main large-scale architecture.

sider only morphological aspects of funnel-like morphologies.

The architecture of MVS crater-type volcanoes can be divided into eight distinctive fundamental architectural elements: (1) root zone, (2) lower and (3) upper diatreme, (4) tephra ring, (5) ring plain, (6) intra-crater cones, (7) overspill wedge and (8) tephra fallout carpet (Figures 12 to 14). The main characteristics of these crater-type volcanoes are presented in Table 3.

Based on the presence of disrupted reflectors showing minor depressions located at the base of the diatreme structures, we interpret that the bottom part of the cratertype volcanoes in the MVS contain a root zone (Figures 12 to 14). In the context of terrestrial maar-diatreme forming eruptions, the root zone is interpreted to be the locus of thermohydraulic explosions [21, 25, 28, 103], and likely contains minor syn-intrusive architectural elements such as contact breccias, disrupted pre-magmatic blocks, and late intrusive plugs $[90,91]$. However, we do not recognise indicative seismic facies that could support the occurrence of these intrusive elements, probably because they are too small to be seismically resolved. In some examples, the possible location of a root zone is coherent with seismic reflectors that correspond to the Amuri and Omihi limestones, and possibly also to the Charteris Bay Sandstone in their deepest parts (Figures 12 and 14). The middle Miocene volcaniclastic rocks sampled in Resolution-1 contain numerous lithics of limestone and very-fine white sandstone [35], which are interpreted to provide evidence that the country rocks of the root zone have experienced intense fragmentation, and were incorporated into the material ejected by high energy explosive eruptions. In 
Table 3: Main characteristics of the architectural elements of the crater-type volcanoes formed during the constructional magmatic stage in the MVS.

\begin{tabular}{|c|c|c|c|c|c|}
\hline Element & Location & Seismic facies & Bounding surfaces & Geometry & Indicative processes \\
\hline Root zone & $\begin{array}{l}\text { Bottom of the } \\
\text { funnel-like } \\
\text { structure. }\end{array}$ & $\begin{array}{l}\text { Moderate to high } \\
\text { amplitude and disrupted } \\
\text { reflectors showing } \\
\text { depression towards the } \\
\text { centre of the structure. }\end{array}$ & Seismically unresolved. & $\begin{array}{l}\text { Unsure, } \\
\text { probably } \\
\text { geoidal. }\end{array}$ & $\begin{array}{c}\text { Brittle deformation. } \\
\text { Post-eruptive subsidence? }\end{array}$ \\
\hline $\begin{array}{l}\text { Lower } \\
\text { diatreme }\end{array}$ & $\begin{array}{l}\text { Centre of the } \\
\text { funnel-like } \\
\text { structure. }\end{array}$ & $\begin{array}{l}\text { Moderate amplitude, } \\
\text { discontinuous and chaotic } \\
\text { reflectors. }\end{array}$ & $\begin{array}{l}\text { Sharp contact between } \\
\text { internal unbedded seismic } \\
\text { facies from external } \\
\text { bedded reflectors. }\end{array}$ & $\begin{array}{l}\text { Funnel- } \\
\text { like. }\end{array}$ & $\begin{array}{l}\text { Brittle deformation. } \\
\text { Excavation into PrErS. } \\
\text { Intense fragmentation and } \\
\text { dispersion of material. }\end{array}$ \\
\hline $\begin{array}{l}\text { Upper } \\
\text { diatreme }\end{array}$ & $\begin{array}{l}\text { Top of the } \\
\text { funnel-like } \\
\text { structure. }\end{array}$ & $\begin{array}{l}\text { Moderate amplitude, } \\
\text { semi-continuous, parallel } \\
\text { and sub-horizontal } \\
\text { reflectors. }\end{array}$ & $\begin{array}{l}\text { Sharp contact between } \\
\text { Internal bedded seismic } \\
\text { facies from external } \\
\text { unbedded seismic facies } \\
\text { below, and mound-like } \\
\text { facies above. }\end{array}$ & $\begin{array}{l}\text { Funnel- } \\
\text { like. }\end{array}$ & $\begin{array}{l}\text { Deposition of layered } \\
\text { material into an upper } \\
\text { crater. }\end{array}$ \\
\hline Tephra ring & $\begin{array}{l}\text { Symmetrically } \\
\text { lateral to the } \\
\text { upper diatreme. }\end{array}$ & $\begin{array}{l}\text { Single high amplitude, } \\
\text { continuous and inclined } \\
\text { reflectors in A shape. }\end{array}$ & $\begin{array}{l}\text { Sharp contacts between } \\
\text { the upper and lower limits } \\
\text { of the high amplitude } \\
\text { reflector. Laterally } \\
\text { gradational to facies of the } \\
\text { ring plain. }\end{array}$ & Ring-like. & $\begin{array}{l}\text { Deposition of "hard" } \\
\text { material in relatively steep } \\
\text { repose angle near a vent } \\
\text { zone. }\end{array}$ \\
\hline Ring plain & $\begin{array}{l}\text { Symmetrically } \\
\text { lateral to the } \\
\text { tephra ring. }\end{array}$ & $\begin{array}{l}\text { Single high amplitude, } \\
\text { continuous, parallel and } \\
\text { sub-horizontal reflectors. }\end{array}$ & $\begin{array}{l}\text { Sharp contacts between } \\
\text { upper and lower limits of } \\
\text { the high amplitude } \\
\text { reflector. Laterally } \\
\text { gradational to facies of the } \\
\text { ring plain. Fade with } \\
\text { increasing distance from } \\
\text { the vent zone. }\end{array}$ & $\begin{array}{l}\text { Circular } \\
\text { tabular, } \\
\text { thinner } \\
\text { with } \\
\text { increasing } \\
\text { distance } \\
\text { from the } \\
\text { vent. }\end{array}$ & $\begin{array}{l}\text { Intense fragmentation and } \\
\text { dispersion of material } \\
\text { ejected from the diatreme. } \\
\text { Deposit parallel to basin } \\
\text { sediments immediately } \\
\text { above PrErS. }\end{array}$ \\
\hline $\begin{array}{l}\text { Intra-crater } \\
\text { cones }\end{array}$ & $\begin{array}{l}\text { Above of the } \\
\text { funnel-like } \\
\text { structure. }\end{array}$ & $\begin{array}{l}\text { Moderate amplitude } \\
\text { reflector with mound-like } \\
\text { shape and transparent } \\
\text { internal seismic facies. }\end{array}$ & $\begin{array}{l}\text { Sharp contacts between } \\
\text { the upper and lower limits } \\
\text { of the mound-like structure } \\
\text { and external bedded } \\
\text { facies. }\end{array}$ & $\begin{array}{l}\text { Mound-like } \\
\text { and } \\
\text { possible } \\
\text { small } \\
\text { cone-like. }\end{array}$ & $\begin{array}{c}\text { Deposition of material } \\
\text { above the upper diatreme. } \\
\text { Late eruptive events? }\end{array}$ \\
\hline $\begin{array}{l}\text { Overspill } \\
\text { wedge }\end{array}$ & $\begin{array}{l}\text { Symmetrically } \\
\text { lateral to the } \\
\text { intra-crater } \\
\text { cones. }\end{array}$ & $\begin{array}{l}\text { High-to-low amplitude, } \\
\text { discontinuous reflectors } \\
\text { that together show a } \\
\text { wedge shape. }\end{array}$ & $\begin{array}{l}\text { Sharp contacts between } \\
\text { upper and lower limits of } \\
\text { the wedge-like structure. } \\
\text { Fade with increasing } \\
\text { distance from the vent } \\
\text { zone. }\end{array}$ & $\begin{array}{c}\text { Circular } \\
\text { wedge-like. }\end{array}$ & $\begin{array}{l}\text { Material that overspill the } \\
\text { tephra ring and deposit } \\
\text { parallel to basin sediments } \\
\text { immediately above the ring } \\
\text { plain. }\end{array}$ \\
\hline $\begin{array}{l}\text { Tephra } \\
\text { fallout } \\
\text { carpet }\end{array}$ & $\begin{array}{c}\text { Seismically } \\
\text { unresolved, but } \\
\text { probably distal } \\
\text { to the funnel-like } \\
\text { structure. }\end{array}$ & $\begin{array}{l}\text { Seismically unresolved, } \\
\text { but probably amalgamated } \\
\text { with reflectors that } \\
\text { represent basin sediments. }\end{array}$ & $\begin{array}{l}\text { Seismically unresolved, } \\
\text { but probably sharp and } \\
\text { parallel contact between } \\
\text { volcaniclastics and Tokama } \\
\text { Siltstone (wire-logs of the } \\
\text { Resolution-1) }\end{array}$ & $\begin{array}{l}\text { Seismically } \\
\text { unresolved, } \\
\text { but } \\
\text { probably } \\
\text { tabular. }\end{array}$ & $\begin{array}{l}\text { Probably represent thin } \\
\text { and tabular layers of } \\
\text { tephra interbedded with } \\
\text { basin sediments. }\end{array}$ \\
\hline
\end{tabular}



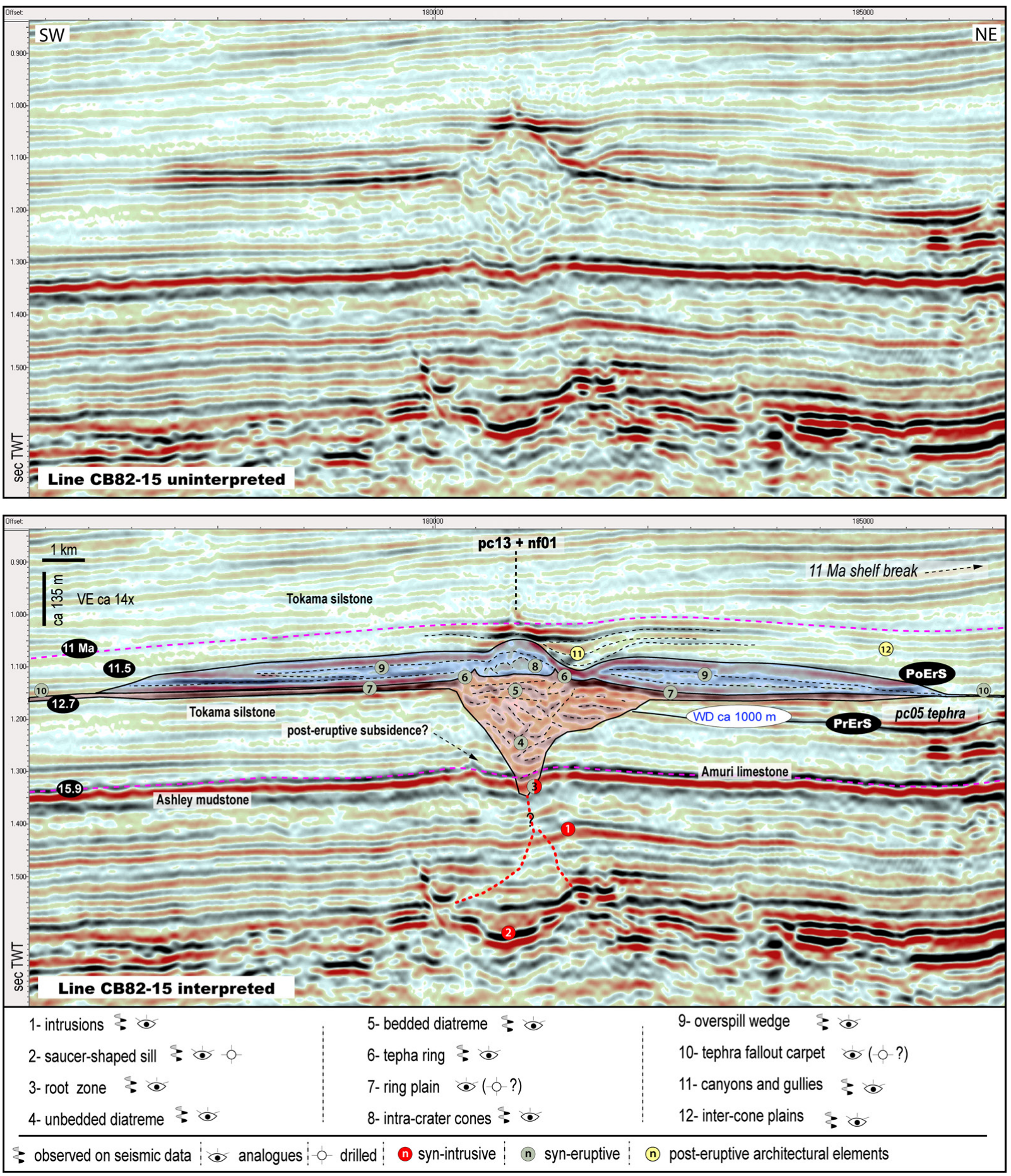

Figure 13: Uninterpreted (above) and interpreted (below) 2D seismic line showing the main architectural elements related to crater-type volcanoes in the MVS. Numbers in red circles are syn-intrusive architectural elements, green are syn-eruptive, and yellow represent postmagmatic architectural elements. We observe that crater-type volcanoes present two distinctive morphologies related to at least two different eruptive-styles: The lower section (in red) shows funnel-like excavation into PrErS and lateral high amplitude parallel reflectors, which we interpret to represent a submarine equivalent of a maar-diatreme volcano. The upper section (in blue) shows cone-like morphology and lateral, wedge shaped, semi-continuous reflectors, which we interpreted as intra-crater volcanoes formed by late eruptive events and associated material that overspills from the rim of the underlying maar-diatreme structure. WD is the approximate water-depth at the time of the formation of the volcanoes [35, 38]. 

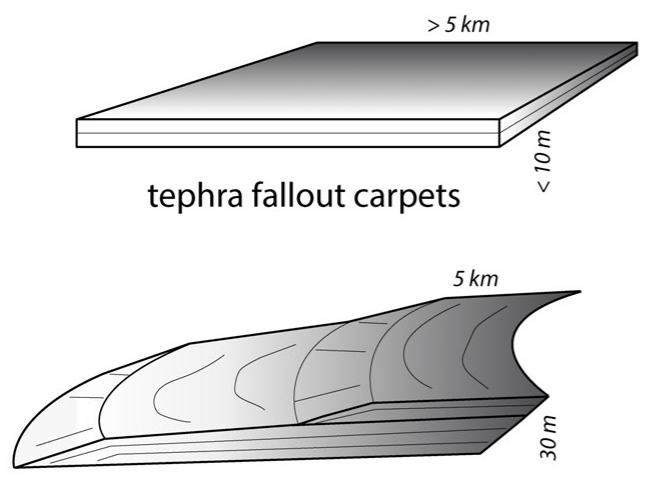

overspill wedge

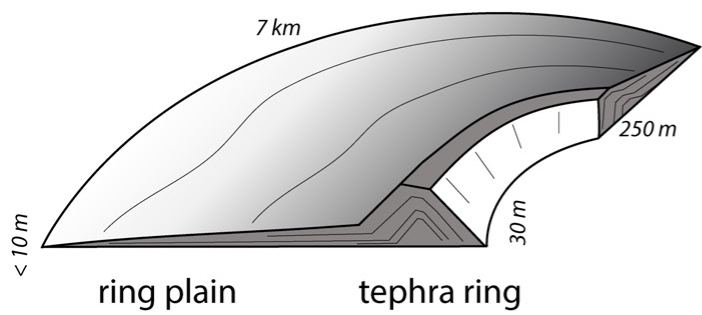

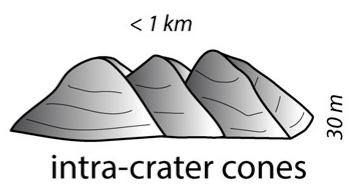

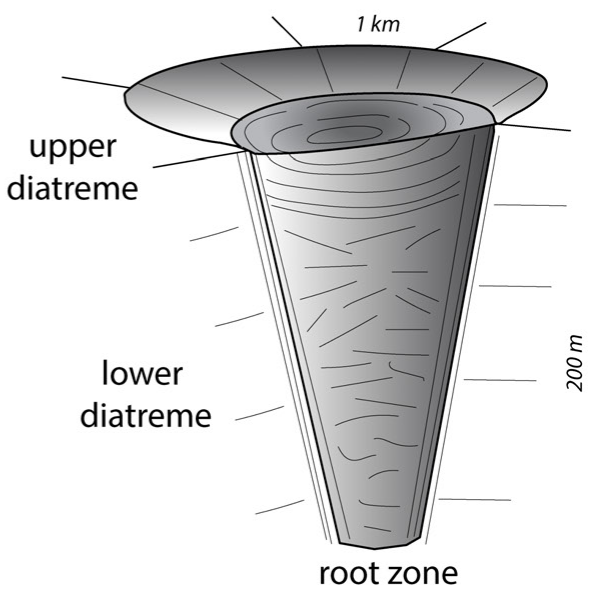

Figure 14: Three-dimensional representation of the main syn-eruptive architectural elements of crater-type volcanoes of the MVS and their average size. Each of these large-scale elements can be constructed by sets of smaller-scale elements formed by the interplay of volcanic activity, external receptor environments, and concomitant sedimentation.

diatremes of the MVS, the depression at the centre of the funnel-like structure may indicate post-eruptive subsidence (Figures 12 and 14).

The lower diatreme comprises a zone with unbedded and chaotic structure below the PrErS (Figures 12 to 14), which suggest that these pre-magmatic sedimentary strata were deformed. The chaotic strata could in dicate processes such as fracturing of the host rock due to shockwaves, crater-wall brecciation and blocks collapsing during large explosive activity $[25,28]$. Another possible process responsible for the unbedded-chaotic seismic character of the lower diatreme zone is the formation of intra-diatreme faults, developed during post-eruptive subsidence $[21,28,105]$. The presence of feeder intrusions of plumbing-type 4 and 5 are likely to occur in the lower diatreme, supported by seismic images showing sub-vertical to sub-horizontal, moderate amplitude reflectors in association with disrupted pre-magmatic blocks (Figures 12 and 13). Intrusive bodies located in the lower part of maardiatreme volcanoes are commonly observed in outcrops elsewhere [21, 25, 28, 90, 91].

The upper diatreme is located immediately above the lower diatreme (Figures 12 to 14). This architectural element, in contrast to what is observed in the lower diatreme, is characterised by a bedded structure, showing seismic reflectivity consistent with the presence of rock bodies deposited sub-horizontally. The seismic aspect of the upper diatreme suggests that this zone is composed of alternating layers, perhaps layers of tephra material sourced from late stage eruptions, together with possible slumps, slides and debris deposits that infill the top part of the diatreme (Figure 12 and 14). Similar stratigraphic relationships are typically observed in analogue diatremes elsewhere $[21,25,28,105]$.

Laterally and symmetrical to both sides of the diatreme, we observe a distinctive parallel and continuous high-amplitude reflector located immediately above the PrErS horizon (Figures 12 and 13), which we interpret to correspond to the tephra ring and ring plain a of a maardiatreme volcano. Morphological and morphometric reconstruction of the MVS volcanoes suggest that these reflectors are inclined at ca $20^{\circ}$ close to the vent zone [38]. These reflectors become progressively sub-horizontal and parallel to basin strata reflectors with increasing distance from the vent. Their high-amplitude continuous seismic character 'fades-out' to become semi-continuous, moderate-to-low amplitude (this last, is the characteristic seismic facies of Tokama Siltstone; Figures 12 and 13). This 'fading-out' character of seismic reflectors with increasing distance from eruptive centres has been interpreted to mark the transition of volcanic to sedimentary rocks $[2,20,53]$. It is possible to map the lateral extent 
of the high-amplitude reflectors for ca $5 \mathrm{~km}$ on both sides of the diatreme structure, which suggests that these reflectors represent material dispersed from the vent zone, possibly formed by high energy explosive eruptions [67]. Near to the diatreme zone, reflectors are steeply inclined and outward-dipping, suggesting that they were formed by accumulation of tephra ejected as ballistic material during pyroclastic eruptions (Figure 12 to 14).

In the study area, bedded diatremes are typically overlain by a dome- and cone-like seismic structure (Figure 12 and 13). These dome and cone morphologies are physically limited by the crater zone of the maar-diatreme volcanoes. Based on their convex upwards geometries, and used in conjunction with examples described in the literature $[21,25]$, we interpret these seismic facies to correspond to intra-crater cones formed by the accumulation of tephra near the eruptive vent. Minor hyaloclastite and pillow-lava material may also be deposited in the crater zone during late stage eruptions, however, we did not find diagnostic features that confirm their occurrence in the MVS.

Lateral to the intra-crater cone and overlying the tephra ring and plain, we observe a characteristic seismic facies composed of discontinuous moderate-amplitude reflectors, here referred to as the overspill wedge. As observed in the tephra ring and ring plain, reflectors of the overspill wedge merge and fade-out with increasing distance from the eruptive centre. This suggests that they were formed by material sourced from the diatreme zone, possibly by ballistics and other dispersal mechanisms related to submarine eruptive plumes (e.g. eruption-fed density currents, [99] (Figure 12 and 13). This wedge has a maximum lateral extent of ca $7 \mathrm{~km}$ from both sides of the diatreme, with reconstructed vertical heights of ca $30 \mathrm{~m}$ [40]. The overspill wedge may also contain minor pillow-lavas and hyaloclastite deposits [25], interbedded with deposits from explosive submarine eruptions. However, we did not identify seismic facies that could confirm the presence of lava-flow deposits in the overspill wedge, perhaps due to lack of seismic resolution.

The presence of thin tuffaceous layers interbedded with the Tokama Siltstone [35] suggests that tephra material could be transported and deposited kilometres from the MVS vents. Studies of submarine-eruption deposits show that material ejected into the water column can be transported by suspension for long distances $(>100 \mathrm{~km})$, to be deposited distal to the eruptive centre as thin and tabular tephra layers [99, 106-111]. Based on this evidence, we infer the presence of a tephra fallout carpet occurring in distal parts of the maar-diatreme volcanoes (Figure 12 to 14), however, this architectural element cannot be directly seismically resolved.

\section{Origin of the crater-type volcanoes}

Crater-type volcanoes of the MVS comprise syn-eruptive architectural elements that show deep craters excavated into the PrErS horizon, and associated deposits that indicate substantial material dispersed laterally from these craters. These observations collectively suggest that cratertype volcanoes were likely formed by high-energy explosive eruptions [28, 112-114], which are rarely interpreted to occur at water depths $>100 \mathrm{~m}$ [81, 115-119]. Detailed stratigraphic mapping coupled with information from the Resolution-1 well provide strong evidence that some cratertype volcanoes of the MVS erupted in a subaqueous environment around $1000 \mathrm{~m}$ deep $[35,38]$. The geometry and spatial arrangement of the architectural elements in the crater-type volcanoes suggest that funnel-like structures are likely to represent the deep-water equivalent of maardiatreme, and basin-like structure possibly correlate with tuff rings volcanoes (Figure 3 and 13).

\section{Cone-type volcanoes}

Cone-type volcanoes are interpreted to be the deep-water equivalent of tuff cones. In contrast to crater-type volcanoes, MVS cone-type volcanoes are characterised in seismic imagery by a sequence of reflectors that pile-up close to the vent zone, forming a convex-upwards curvature of the PoErS above the PrErS horizon with minor excavation into pre-eruptive strata (Figures 15, 16 and 19). This volcano-type more commonly occurs as isolated cones, typically ranging in size from 1 to $3 \mathrm{~km}$ in diameter, and 100 to $300 \mathrm{~m}$ in height [38]. Seismic data show that the subvent zone of this volcano-type contains high-amplitude reflectors that may represent intrusions related to plumbingtypes 3, 4 and 5 (Figure 8, 16 and 19). However, most MVS cone-type volcanoes appear to be fed by large sill intrusions related to plumbing-types 1 and 3 . The exception is the overlapped volcanic cluster (Figure 8) that appears to be fed by plumbing-type 5 , and does not show evidence that it is fed by a shallow $(<1 \mathrm{~km})$ magmatic chamber.

The syn-eruptive architecture of the cone-type volcanoes of the MVS can be divided into five fundamental elements, based on distinctive seismic facies, and the surfaces that bound characteristic morphologies. These architectural elements are: (1) basal cone, (2) central crater, (3) tephra flank, (4) cone apron and (5) tephra fallout car- 
Table 4: Main characteristics of the architectural elements of the cone-type volcanoes formed during the constructional magmatic stage in the MVS.

\begin{tabular}{|c|c|c|c|c|c|}
\hline Element & Location & Seismic facies & Bounding surfaces & Geometry & Indicative processes \\
\hline Basal cone & $\begin{array}{l}\text { Bottom of the } \\
\text { cone-like } \\
\text { structure. }\end{array}$ & $\begin{array}{l}\text { Moderate to high } \\
\text { amplitude sub-horizontal } \\
\text { and parallel reflectors. }\end{array}$ & $\begin{array}{l}\text { Sharp to gradational } \\
\text { contact between internal } \\
\text { sub-horizontal and } \\
\text { parallel facies, from } \\
\text { external seismic facies } \\
\text { with inclined, disrupted } \\
\text { or chaotic reflectors }\end{array}$ & $\begin{array}{l}\text { Unsure, } \\
\text { probably } \\
\text { tabular. }\end{array}$ & $\begin{array}{l}\text { Material piled-up near } \\
\text { vent, sub-parallel to } \\
\text { basin sediments and } \\
\text { above the PrErS. }\end{array}$ \\
\hline $\begin{array}{l}\text { Central crater or } \\
\text { vent zone }\end{array}$ & $\begin{array}{l}\text { Centre of the } \\
\text { cone-like } \\
\text { structure. }\end{array}$ & $\begin{array}{l}\text { Typically transparent, but } \\
\text { also show moderate to } \\
\text { low amplitude, } \\
\text { discontinuous, chaotic or } \\
\text { parallel reflectors } \\
\text { dipping inward the } \\
\text { central crater. }\end{array}$ & $\begin{array}{l}\text { Sharp to erosive contact } \\
\text { between internal chaotic } \\
\text { seismic facies from } \\
\text { external facies typically } \\
\text { bedded and inclined. }\end{array}$ & $\begin{array}{l}\text { Probably } \\
\text { cylindrical } \\
\text { based in } \\
\text { analogues. }\end{array}$ & $\begin{array}{l}\text { Material disperse out of } \\
\text { the crater zone. Chaotic } \\
\text { deposits probably } \\
\text { represent collapses of } \\
\text { the crater walls, and } \\
\text { deposition of intra-crater } \\
\text { layers of tephra. }\end{array}$ \\
\hline Tephra flank & $\begin{array}{l}\text { Symmetrically } \\
\text { lateral to the } \\
\text { central crater. }\end{array}$ & $\begin{array}{l}\text { Moderate to low } \\
\text { amplitude, } \\
\text { semi-continuous, parallel } \\
\text { and inclined reflectors } \\
\text { dipping outwards from } \\
\text { the central crater zone. }\end{array}$ & $\begin{array}{l}\text { Sharp to erosive contact } \\
\text { between internal inclined } \\
\text { and bedded seismic } \\
\text { facies from external } \\
\text { chaotic (towards the } \\
\text { central crater) or } \\
\text { sub-parallel seismic } \\
\text { facies (towards the } \\
\text { basin). }\end{array}$ & Conical. & $\begin{array}{l}\text { Deposition of layered } \\
\text { material near a vent zone } \\
\text { and above the basal } \\
\text { cone, or above PrErS. }\end{array}$ \\
\hline Cone apron & $\begin{array}{l}\text { Symmetrically } \\
\text { lateral to the } \\
\text { tephra flank. }\end{array}$ & $\begin{array}{l}\text { Low to high amplitude, } \\
\text { typically continuous and } \\
\text { sub-parallel and } \\
\text { sub-horizontal reflectors. }\end{array}$ & $\begin{array}{l}\text { Sharp to gradational } \\
\text { between bedded seismic } \\
\text { facies that pinch with } \\
\text { increasing distance from } \\
\text { the eruptive centre. }\end{array}$ & Ring-like. & $\begin{array}{c}\text { Deposition of material } \\
\text { distal to a vent zone and } \\
\text { above PrErS }\end{array}$ \\
\hline $\begin{array}{c}\text { Tephra fallout } \\
\text { carpet }\end{array}$ & $\begin{array}{c}\text { Seismically } \\
\text { unresolved, but } \\
\text { probably distal } \\
\text { to the funnel-like } \\
\text { structure. }\end{array}$ & $\begin{array}{l}\text { Seismically unresolved, } \\
\text { but probably } \\
\text { amalgamated with } \\
\text { reflectors that represent } \\
\text { basin sediments. }\end{array}$ & $\begin{array}{l}\text { Seismically unresolved, } \\
\text { but probably sharp and } \\
\text { parallel contact between } \\
\text { volcaniclastics and } \\
\text { Tokama Siltstone } \\
\text { (wire-logs of the } \\
\text { Resolution-1) }\end{array}$ & $\begin{array}{l}\text { Seismically } \\
\text { unresolved, } \\
\text { but } \\
\text { probably } \\
\text { tabular. }\end{array}$ & $\begin{array}{l}\text { Probably represent thin } \\
\text { and tabular layers of } \\
\text { tephra interbedded with } \\
\text { basin sediments. }\end{array}$ \\
\hline
\end{tabular}

pet (Figures 15 to 19). The main characteristics of the syneruptive architectural elements of this volcano-type are shown in Table 4.

The basal cone is characterised by sub-horizontal and parallel reflectors of high- to moderate-amplitude that are located near the interpreted vent zone (Figure 15). The geometries and seismic characteristics of the basal cone comprise sets of stacked reflectors, suggesting deposition of alternating tephra layers and perhaps deposits such as subaqueous lavas and hyaloclastites formed during the initial eruptive stages of the cone construction (Figures 8, 15, 16 and 19). In addition, the presence of high-amplitude reflectors cross-cutting sub-horizontal reflectors may indicate that the basal cone also contains minor shallow intrusions of plumbing type-4 (Figure 8), which are commonly ob- served in monogenetic volcanoes elsewhere $[25,27,34,87$, 88].

The central crater or vent zone is characterised by disrupted, chaotic and layered reflectors inwardly-dipping towards the centre of the cone structure (Figures 15, 16, 18 and 19), providing evidence that deposits locally infilled a negative shallow depression above the PrErS horizon. This architectural element is typically located overlying seismic facies that indicate the presence of magmatic conduits and intrusive bodies (i.e. disrupted pre-magmatic reflectors, high-amplitude reflectors cross-cutting enclosing strata), as shown by $[6,94,95,120]$ in buried volcanic systems elsewhere. The structure of the central crater shows only minor excavation into the PrErS horizon, which suggests that eruptions in cone-type volcanoes were much less damaging to the host rocks than what is observed in 

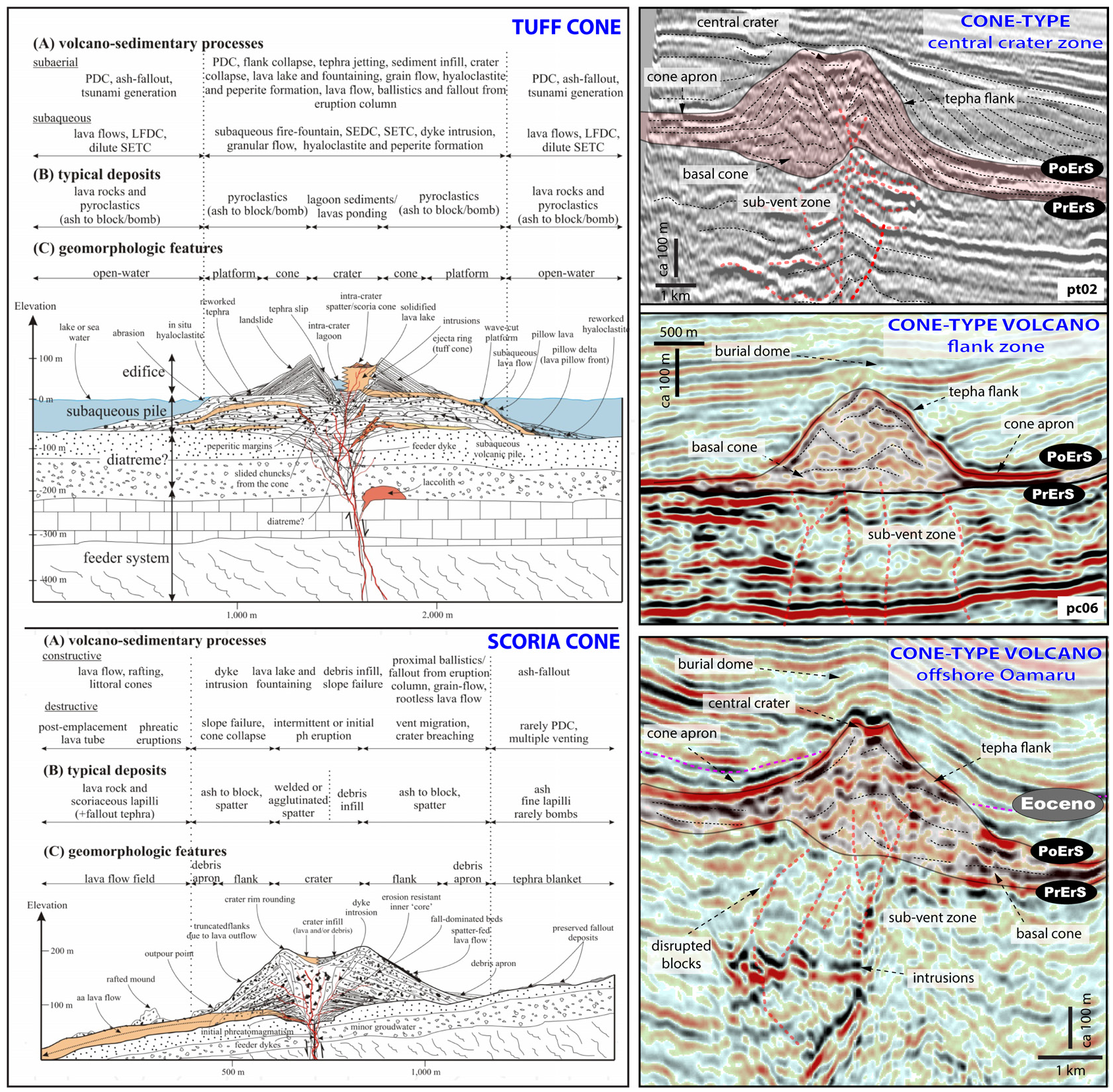

Figure 15: Images on the left show schematic cross-sections through tuff and scoria cones showing their typical volcano-sedimentary processes, deposits and morphology from [25]. Seismic images on the right show interpreted 2D lines of MVS cone-type volcanoes, and their large-scale architecture. The seismic section in the lower corner shows a buried submarine Eocene volcano $40 \mathrm{~km}$ offshore of Oamaru [50], which is interpreted to be part of the Waiareka-Deborah monogenetic volcanic field, and was used as analogue for our interpretations.

the crater-type volcanoes [114]. We interpret this architectural element to have been formed by mechanisms such as jets of tephra, followed by reworking and deposition of material into the central crater. Outcrop observations of ancient volcanoes in the Waiareka-Deborah volcanic field, South Island of New Zealand, show that the crater zone of submarine monogenetic volcanoes typically contain massive, chaotic, to amalgamated deposits of lapilli-tuff to tuff- breccia, formed by tephra jets and ballistics during explosive eruptions, and deposits of tephra dipping inwards in the crater zone [101, 121, 122].

The tephra flank is characterised by inclined, lowto moderate-amplitude reflectors dipping outward from the centre of the cone-shaped structure (Figure 16). We interpret the flanks of MVS cone-type volcanoes to predominately contain fragmented material that originated 


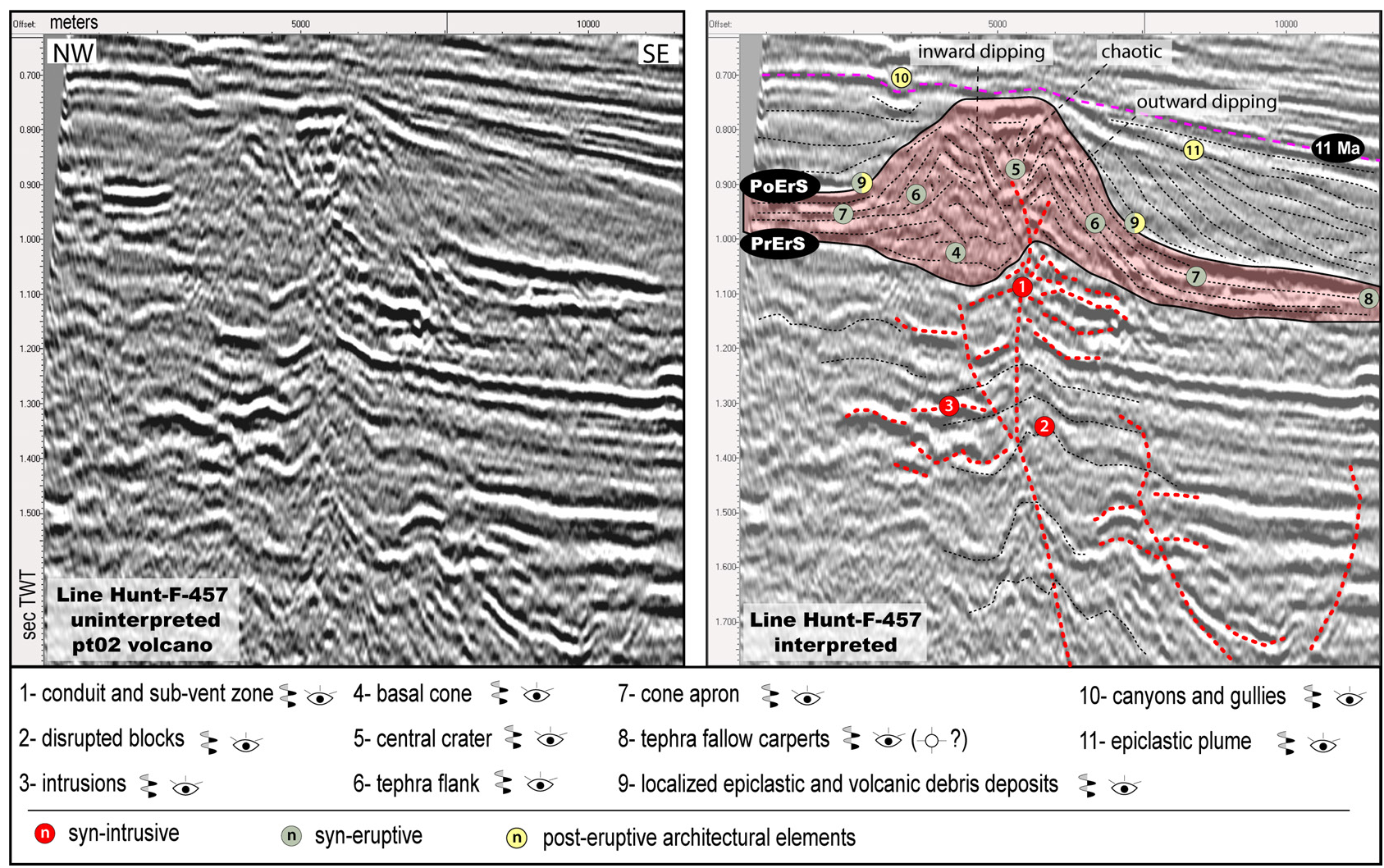

Figure 16: Uninterpreted (left) and interpreted (right) 2D seismic line showing the main architectural elements related to cone-type in the MVS. Numbers in red circles are syn-intrusive architectural elements, green are syn-eruptive, and yellow show post-magmatic architectural elements. Cone-type volcanoes are mainly composed of a basal cone, a central crater, a tephra flank and a cone apron. These volcano-types produce upward convex morphologies between the PrErS and PoErS horizons, which we have interpreted to represent the submarine equivalents of tuff cones. Note that the central-crater shows inward-dipping reflectors while the tephra flank shows outward-dipping reflectors and minor excavation into the PrErS horizon.

from submarine pyroclastic eruptions, rather than subaqueous lava flow deposits. This interpretation is supported by: (i) a clear lateral relationship of the tephra flank with a crater (vent) zone that suggests explosive activity, (ii) seismic facies showing low- to moderate amplitude ${ }^{1}$, semi-continuous, parallel and inclined reflectors, symmetrically dipping away from the vent zone ${ }^{2}$ and, (iii) rocktypes collected in the Resolution-1 well indicate explosivity in the MVS (peloidal fragments enveloped by palagonite films, broken crystals and relics of bubble walls; [35]. However, some minor lavas and hyaloclastite deposits are commonly observed in explosive monogenetic volcanoes elsewhere [25]. Thus, these lava deposits (and pos-

1 Typically, lava flow deposits show high-amplitude continuous reflectors. Volcaniclastic material usually show moderate amplitude reflectors (e.g. [3, 20]).

2 This stratal relationships are commonly observed for deposits formed by explosive eruptions in both subaerial and submarine environments $[25,99,101,102]$. sibly also type- 4 intrusions) are expected to occur in the tephra flank, which is suggested by localised and isolated high-amplitude reflectors. Deposits of the flanks of monogenetic submarine volcanoes are typically formed by eruption-fed density currents and comprise tabular, thinlybedded layers of tephra dipping away from the vent zone, [101, 102, 121]. Eruption-fed density currents usually form well-sorted and thinly-bedded pyroclastic deposits similar to $\mathrm{Td}$ and Te turbidite facies of the Bouma sequence [99, 123]. These bedded tuffaceous rocks are possible lithofacies that may occur on the tephra flanks of MVS volcanoes (Figure 17).

The cone apron is characterised by sub-horizontal and parallel reflectors that pinch and amalgamate with basin reflectors as distance increases from the cone structure (Figures 15, 16 and 19). The Resolution-1 well penetrates the distal part of the cone apron of the volcano pc14 (Figure 1), recovering thin layers of tephra interbedded with siltstones [35]. Based on this evidence, we interpret the cone apron to be comprised of fine-grained layers of tephra 

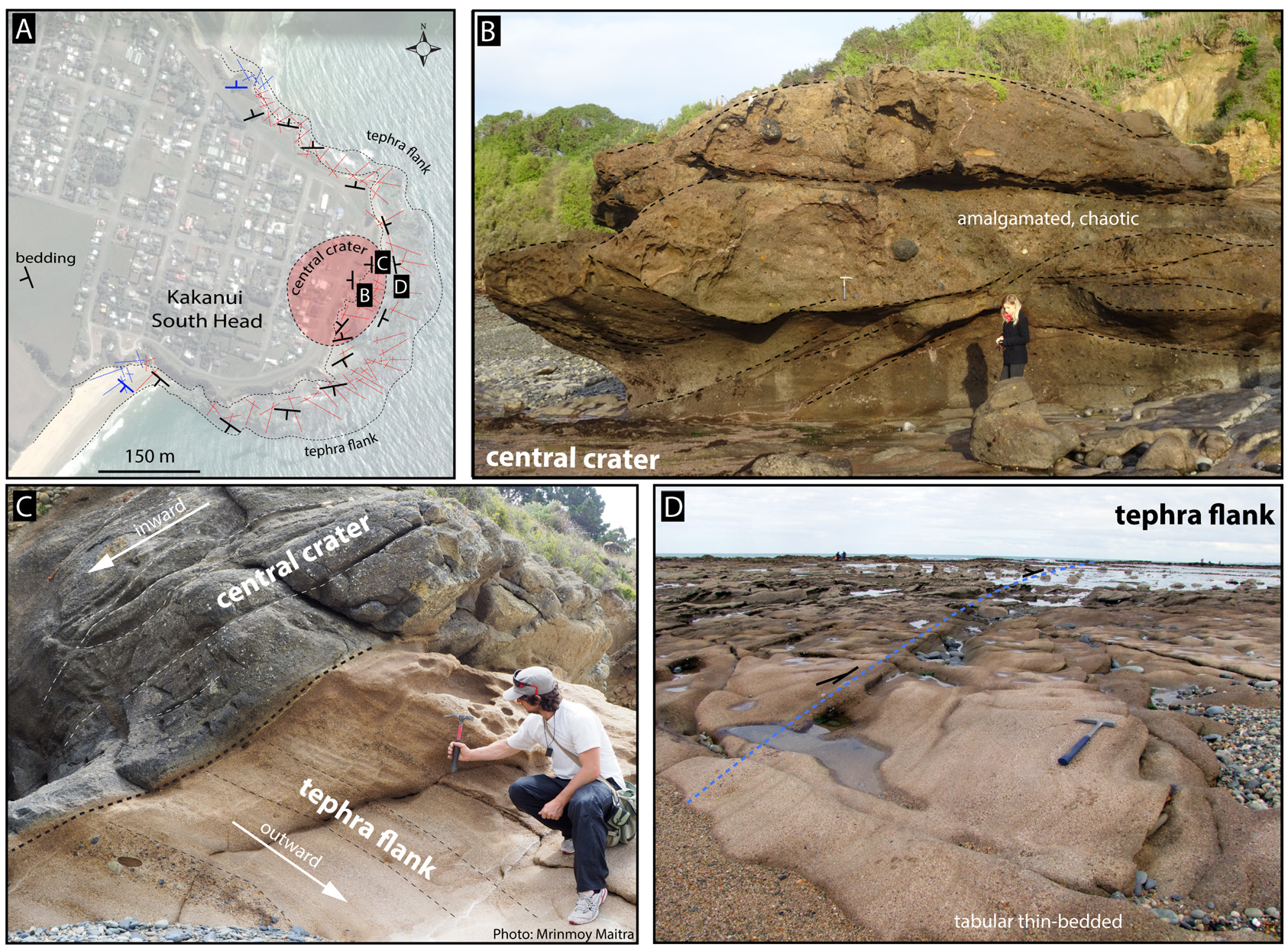

Figure 17: Photographs of potential analogue for MVS syn-eruptive architectural elements outcropping in Kakanui South Head submarine volcanic edifice, near Oamaru, South Island of New Zealand. A) Map showing the location of the vent and flanks of the cone. B) Massive, chaotic to amalgamated intra-crater lapilli-tuff to tuff-breccia interpreted to be deposited by tephra jets, ballistic and debris flow of material remobilized into the central crater [121,122]. C) Angular contact between amalgamated beds dipping inward towards the central crater, and tabular layers of tephra outwardly dipping towards the flanks of the edifice. D) Thin-bedded, tabular, semi-circular layers of lapilli-tuff formed by low-volume tephra jetting and eruption-fed density currents deposited at the flanks of the volcanic edifice [104, 121].

transported by subaqueous eruption plumes, likely interbedded with reworked material from cone collapses and degradation, a phenomena commonly observed in volcanoes elsewhere $[25,102,124]$. The cone apron may also contain minor subaqueous lavas that overspill from the crater rim, and possible peperitic material associated with invasive lavas and/or shallow type-4 intrusions [15]. The 3D seismic interpretation of a submarine monogenetic field along the southern Australian margin shows that submarine lava-flows could extend for more than $30 \mathrm{~km}$ from the eruptive centre [20].

The tephra fallout carpet of cone-type volcanoes (like their counterpart crater-type volcanoes) is seismically unresolved and thus must be based on studies elsewhere [99, 109, 111]. Submarine eruption plumes (and also subaerial pyroclastic density currents entering the water) can introduce pyroclasts and rock fragments into the water column, while residual buoyant material remains suspended and can be transported by oceanic currents $[106,107,110$, 123]. Rafts of highly vesiculated pumice can travel long distances when carried by currents $[125,126]$. When saturated in water, these fragments sink and can form deposits with size varying from ash to blocks [106]. These processes are possible to have occurred in the MVS.

\section{Origin of the cone-type volcanoes}

MVS cone-type volcanoes contain syn-eruptive architectural elements that show reflectors piling-up above the PrErS horizon. The vent structure of these volcanoes shows minor excavation into the PrErS horizon, which sug- 


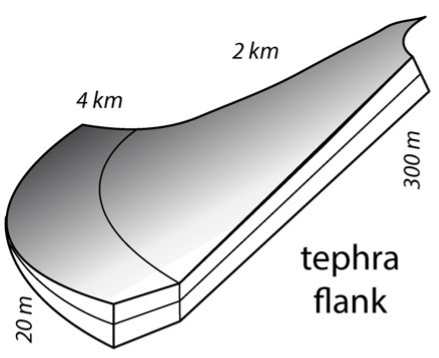

cone apron

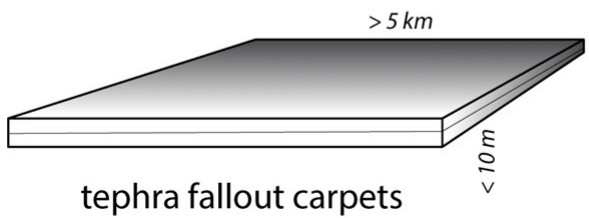

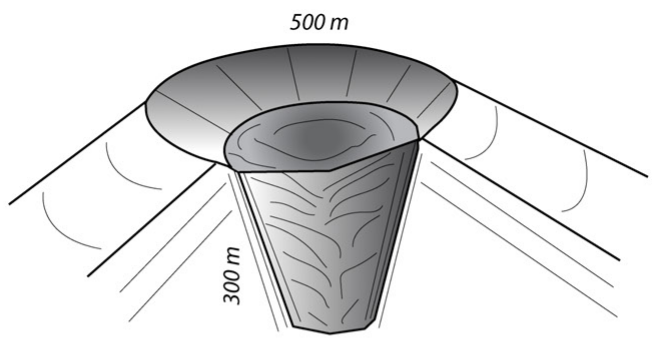

central crater

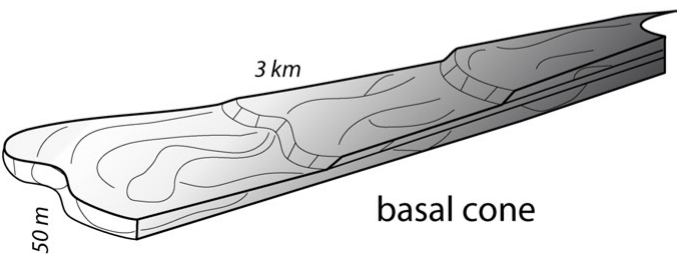

Figure 18: Three-dimensional representation of the main syn-eruptive architectural elements of cone-type volcanoes of the MFS and their average size. Each of these large-scale elements can contain sets of smaller-scale architectural elements formed by the interplay of volcanism and concomitant sedimentation.

gests that the effects of eruptions on the host rocks are minimal, when compared to those of crater-type volcanoes [114]. The flanks of cone-type volcanoes typically are outward-dipping from the central crater and display lowto moderate-amplitude, which suggests that they more likely comprise fragmented material ejected during pyroclastic eruptions rather than formed by lavas.

The tephra flank and cone apron of cone-type volcanoes predominantly have low slope angles $\left(<16^{\circ}\right)$, typically displaying widespread seismically detected boundaries up to $6 \mathrm{~km}$ from the central crater. This geometric characteristic together with information from rock textures recovered in Resolution-1 (possible armoured lapilli and ash aggregates) suggests that this volcano-type represents a deep-water equivalent of tuff cones [35, 38]. However, we do not reject the possibility that spatter cones and pillow mounds also occur in the MVS, which could be verified by acquiring additional high quality 3D seismic data and/or drilling holes proximal to their eruptive vents.

\section{Eruption-related sedimentary architectural elements}

Sedimentological and volcanological processes observed on modern volcanoes [11, 25, 26, 67, 124], suggest that the syn-eruptive interval of the MVS may comprise sedimentary deposits triggered by simultaneous eruptions, together with primary volcanic eruptive deposits. Processes related to the eruptions such as earthquake shockwaves, submarine explosions, and magmatic inflation are potential triggers for debris flows, submarine landslides and cone-sector collapses (e.g. submarine landslides triggered by the 2009 eruption at NW Rota-1 volcano, Mariana arc; [127]. Tephra material can be reworked during or immediately after eruptions by mechanisms such as submarine currents, waves and tsunamis [25, 128]. Based on the available 2D seismic data and a limited number of wells, distinguishing eruptive volcanic deposits from eruption-related sedimentary deposits, or from resedimented epiclastic deposits is not always possible. We tentatively infer five settings in which distinctive sets of eruption-related sedimentary architectural elements can form (Figures 6,16 and 19), based on seismic facies that could indicate reworking of parts of the volcanic edifices during the syn-magmatic stage (e.g. chaotic seismic facies, sediment waves). These five settings are: (1 and 2) the crater zone of both volcano types; (3) the flanks of cone-type volcanoes; (4) the tephra ring of crater-type volcanoes; (5) the cone apron of conetype volcanoes.

The crater zone of MVS volcanoes may contain sedimentary deposits controlled by gravitational flows and other types of mass transport deposits that infill the space created by explosions and ground collapses during (and immediately after) eruptions. Common sedimentary facies in the crater zone may include course-grained, massive, chaotic and amalgamated deposits formed by tephra re- 

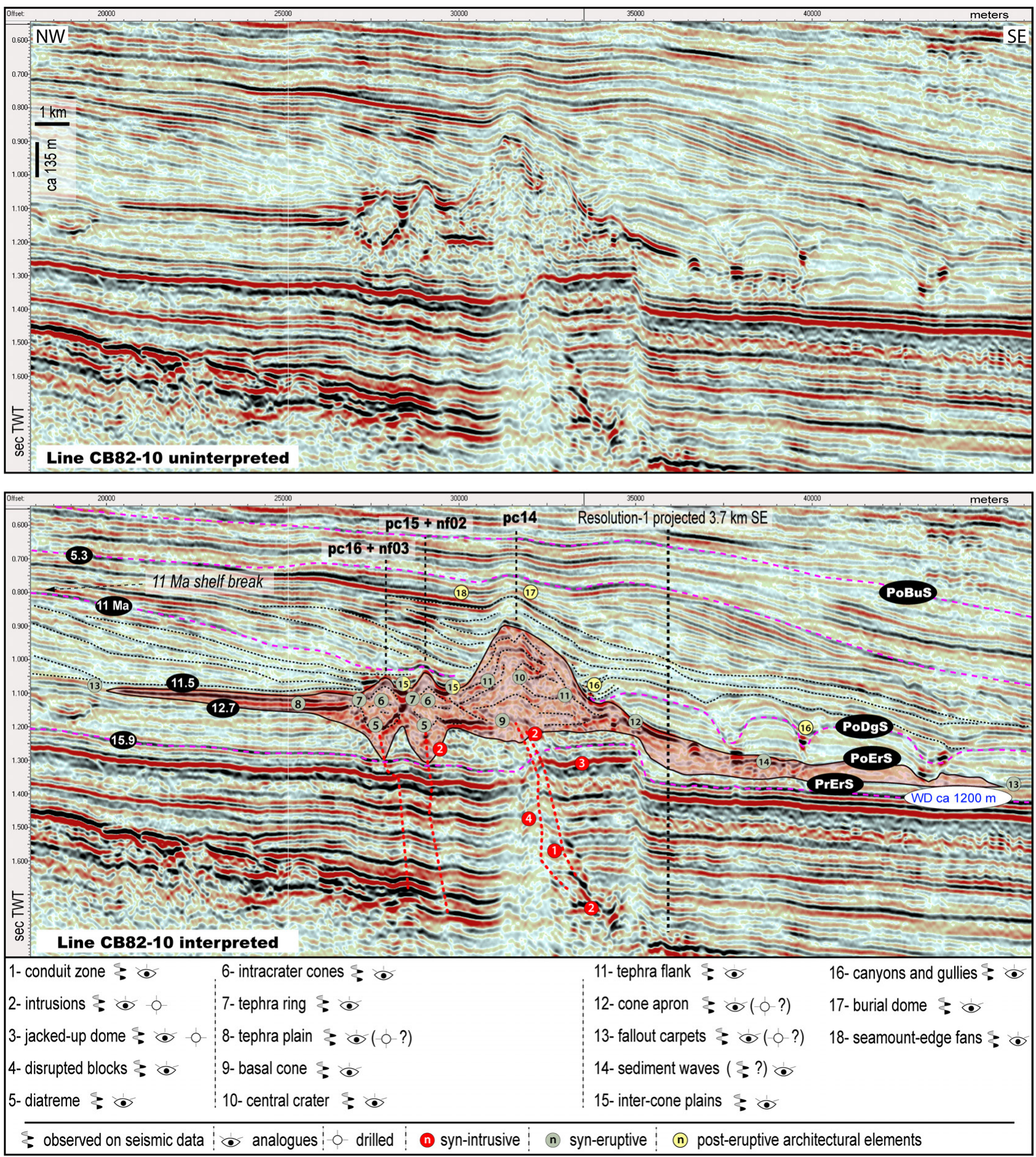

Figure 19: Uninterpreted (above) and interpreted (below) 2D seismic line showing the main architectural elements related to cone-type volcanoes in the MVS. Numbers highlighted in red are syn-intrusive architectural elements, green are syn-eruptive, and yellow are postmagmatic architectural elements. Based on seismic stratigraphic interpretation, the lower sequence of volcaniclastics recovered in Resolution-1 was probably sourced from volcanoes located towards the NW or W of the well (possible nf02 and nf03). Tuffs from -1103 to $-1110 \mathrm{~m}$ depth were likely vented from pc14. WD is the estimated water depth at the time of the formation of these volcanoes [35, 38]. 
working followed by slip and deposition into the crater (Figure 17), and by slide and slump blocks collapsed from the crater walls $[25,28,114]$. On the flanks of cone-type and along the tephra ring of crater-type volcanoes, material reworking by currents and mass-wasting are important synand post-eruptive process $([101,106,124,129]$. On the cone apron of pc-14 (Figure 19), seismic images show a characteristic facies that resembles sediment waves occurring between the PrErS and PoErS horizons, which may represent syn-eruptive submarine landslides such as those reported by [124].

\subsubsection{Inter-eruptive architectural elements}

Monogenetic volcanic fields are typically characterised by a cluster of dispersed and isolated volcanoes formed by one eruptive cycle with minor interruptions $[13,24,25$, $88,100]$. Individual volcanoes are typically diachronous with one another, each having an active life of years to centuries [13], and the complete volcanic field taking hundreds of thousands to a few million years to form [130-134]. Therefore, despite the fact that monogenetic volcanoes are defined by short eruptive periods, the magmatic system itself may have been long lived [88].

In our volcano-stratigraphic model (Figure 4 and 6), inter-eruptive architectural elements can be formed in association with volcanoes that have finished their eruptive cycle, but may have begun to degrade and interact with basin sedimentation while volcanism is still active in other parts of the MVS. In polygenetic volcanoes, syn-and intereruptive deposits are commonly interbedded near a relatively stationary eruptive centre. By contrast, in monogenetic volcanic fields, these inter-eruptive sedimentary deposits typically are interbedded with primary volcanic deposits erupted from diverse and scattered vents. In the MVS, inter-eruptive architectural elements are represented by sedimentary rocks of the Tokama Siltstone interbedded with volcaniclastic rocks that likely were erupted from different MVS vents. In addition, inter-eruptive deposits related to mass transport and erosion of inactive volcanoes are likely to occur in the MVS, although, we cannot separate these rock units from syn-eruptive sedimentary deposits, due to limitations in the resolution of the seismic dataset.

\subsection{Post-Magmatic Sequence}

Sedimentary processes, such as erosion and burial of the volcanic edifice, are dominant during the post-magmatic sequence (Figure 4 and 6). After the magmatic activity in the MVS had ceased at ca $11.5 \mathrm{Ma}$ [35], the submarine volcanic morphology had a strong impact on the sedimentation patterns of the study area. We divide the postmagmatic sequence into degradational and burial stages. Each stage is marked by different processes of erosion and burial of the volcanic edifices, which control the formation and distribution of MVS post-magmatic architectural elements.

\subsubsection{Degradational stage: rate of erosion $>$ rate of burial}

The degradational stage is marked by high rates of erosion of the MVS edifices. We place the PoDgS coincident with a late Miocene (lM) unconformity, because this erosive surface represents the last significant event that degraded the volcanic edifices [38] (Figure 6). Architectural elements of this stage comprise canyons, gullies, localised epiclastic deposits and contemporaneous non-volcanogenic sedimentary deposits impacted by the presence of the volcanoes (Figures 13, 16, 19 and 20).

Canyons and gullies are usually associated with the PoDgS and vary in size from $<100 \mathrm{~m}$ to $1100 \mathrm{~m}$ wide and up to ca $175 \mathrm{~m}$ deep, considering the acoustic velocity of 2500 $\mathrm{m} / \mathrm{s}$ for the Tokama Siltstone recorded in sonic wire-logs of Resolution-1. Channels are narrow towards shallow water and wider and more deeply incised at the slope/abyssal interface. Occasionally these channels are stacked at the base of the tephra flank and cone apron of cone-type volcanoes (Figure 19). Canyon erosion can remove material from the volcano flanks, which may cause instability and collapse of parts of the cone, forming localised small debris deposits (Figure 6). However, if these debris deposits occur in the MVS they are seismically unresolved with the available dataset.

Volcanoes with flattened tops concordant with the PoDgS typically show reflectors downlapping from the edifice onto the basin floor, suggesting that these volcanoes provide a local source of epiclastic sediments (Figure 6 and 20). Seismic attribute analysis shows that these deposits likely contain material eroded from the volcanoes, due to their similarity in seismic impedance analysed from diverse seismic attributes (Figure 20). This degradational seismic facies only occur in association with reconstructed volcanoes $>200 \mathrm{~m}$ high located proximal to the 11 Ma shelfbreak [38]. We interpret this degradation facies to represent a plume of epiclastic sediments eroded from volcanoes that were emergent and/or eroded in a shallow marine environment by the action of waves and shallow cur- 

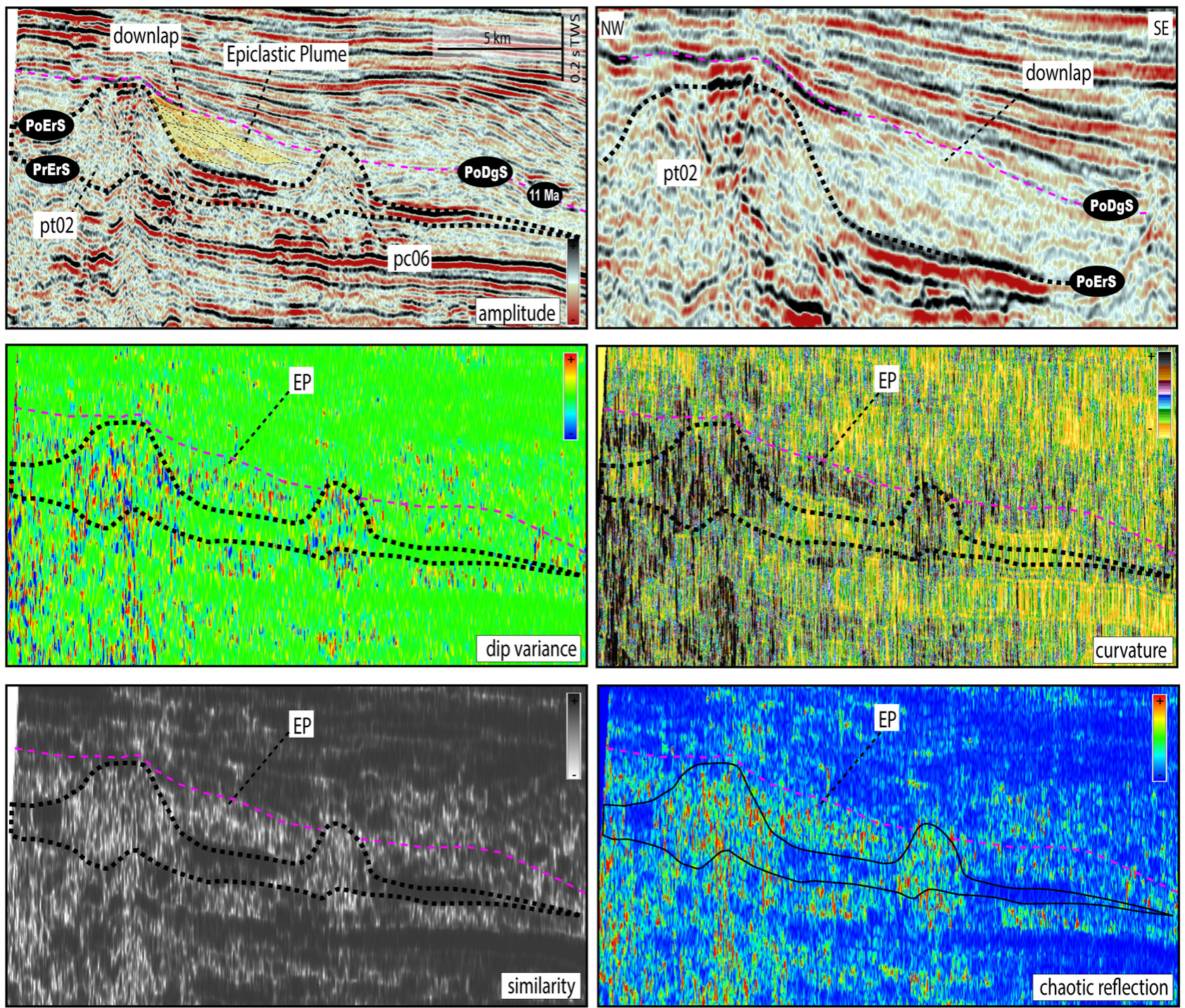

Figure 20: Seismic attribute analysis of pt02 and pc06 volcanoes. Note that the seismic attributes show similarity between the internal and external parts of pt02, which we interpreted as a plume of sediments deposited after erosion of extinct volcanic islands during the degradational stage.

rents. The epiclastic plume is deposited parallel with the direction of the prograding clinoforms, with maximum seismically detected horizontal and vertical dimensions of up to $3 \mathrm{~km}$ and $70 \mathrm{~m}$, respectively. The epiclastic plume probably represents sediments deposited next to extinct volcanic islands that had emerged above sea-level by the late Miocene (Figure 20). Similar seismic facies are evident in the Vulcan-3D seismic dataset, located in the offshore Taranaki Basin (Bischoff, unpublished data).

Among cone-type volcanoes, we observed a characteristic seismic facies comprising horizontal and parallel continuous reflectors, here referred to as inter-cone plains (Figure 6, 21 and 22). The seismic facies of the inter-cone plains are similar (moderate-amplitude, semi-continuous and parallel reflectors) to those intersected by the Resolution-1 where fine-grained sedimentary rocks of the Tokama Siltstone were recovered. This seismic character suggests that the inter-cone plains were mostly confined to volcanic edifices, and formed by non-volcanogenic sedimentary strata deposited by processes of decantation in a low-energy environment. However, minor epiclastic deposits may occur next to the flanks of the volcanoes, interbedded with sediments of the inter-cone plains. Figure 23 shows the paleogeography of the study area at the time of the formation of the PoErS horizon, and the location of the shelf-break position at $11 \mathrm{Ma}$ (PoDgS). 

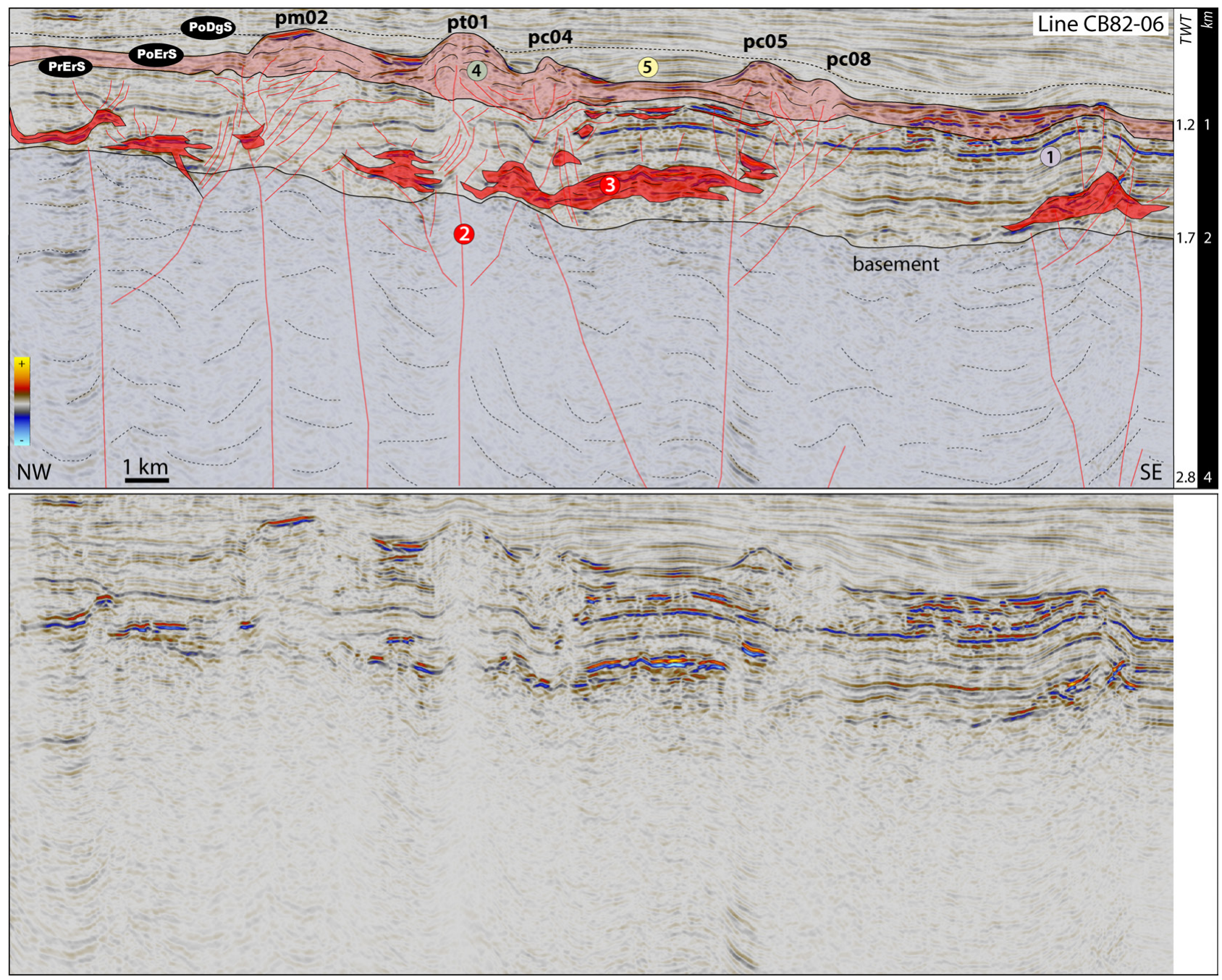

Figure 21: 2D dip section showing the morphology of some of the volcanoes in the MVS. Note a progressive westward increase in degradation of volcanoes pc08 to pm02, relative to the development of a late Miocene (PoDgS) unconformity. Numbers in circles are (1) jacked-up dome, (2) conduit zones, (3) intrusions, (4) cone-type volcanoes, (5) inter-cone plains. Modified from [38].

\subsubsection{Burial stage: rate of burial > rate of erosion}

In seismic images, the burial stage of the MVS is characterised by stratal geometries showing evidence that the volcanic edifies impacted local sedimentation for millions of years after they were buried. This stage is marked by high rates of burial and little or no degradation of the volcanic edifices that remained unburied after the late Miocene unconformity (i.e. PoDgS). Seismic reflectors above eleven cone-type volcanoes display a domal structure, here referred to as burial dome, suggesting the presence of a persistent bathymetric high after these volcanoes were buried (Figure 19). The processes that resulted in the production of the burial dome likely include differential compaction between the volcanic and enclosing sedimentary strata $[6,81,135]$.
Because the impact of buried volcanoes in the basin architecture varies from one volcano to another, we place the PoBuS according to observations from domes located above the volcano pc14, which show impacts in the geometry of overlying strata until at least the Opoitian NZ stage (ca $5 \mathrm{Ma}$; Figure 19). Canyon scars located on the edges of the burial dome above pc14 provide evidence that the location of this buried edifice impacted basin sedimentation until at least ca 6 Myr after volcanism in the MVS has ceased, and ca $1 \mathrm{Myr}$ after pc14 was completely buried. Seismic images of these peripheral canyons (i.e. around the margins of the burial domes) are likely to be associated with the deposition of submarine fans up to $2 \mathrm{~km}$ wide (Figure 19). Fans such as these are well imaged from 3D seismic data over the buried Kora Volcano, in the offshore Taranaki Basin, referred to as seamount-edge fans by [6]. 


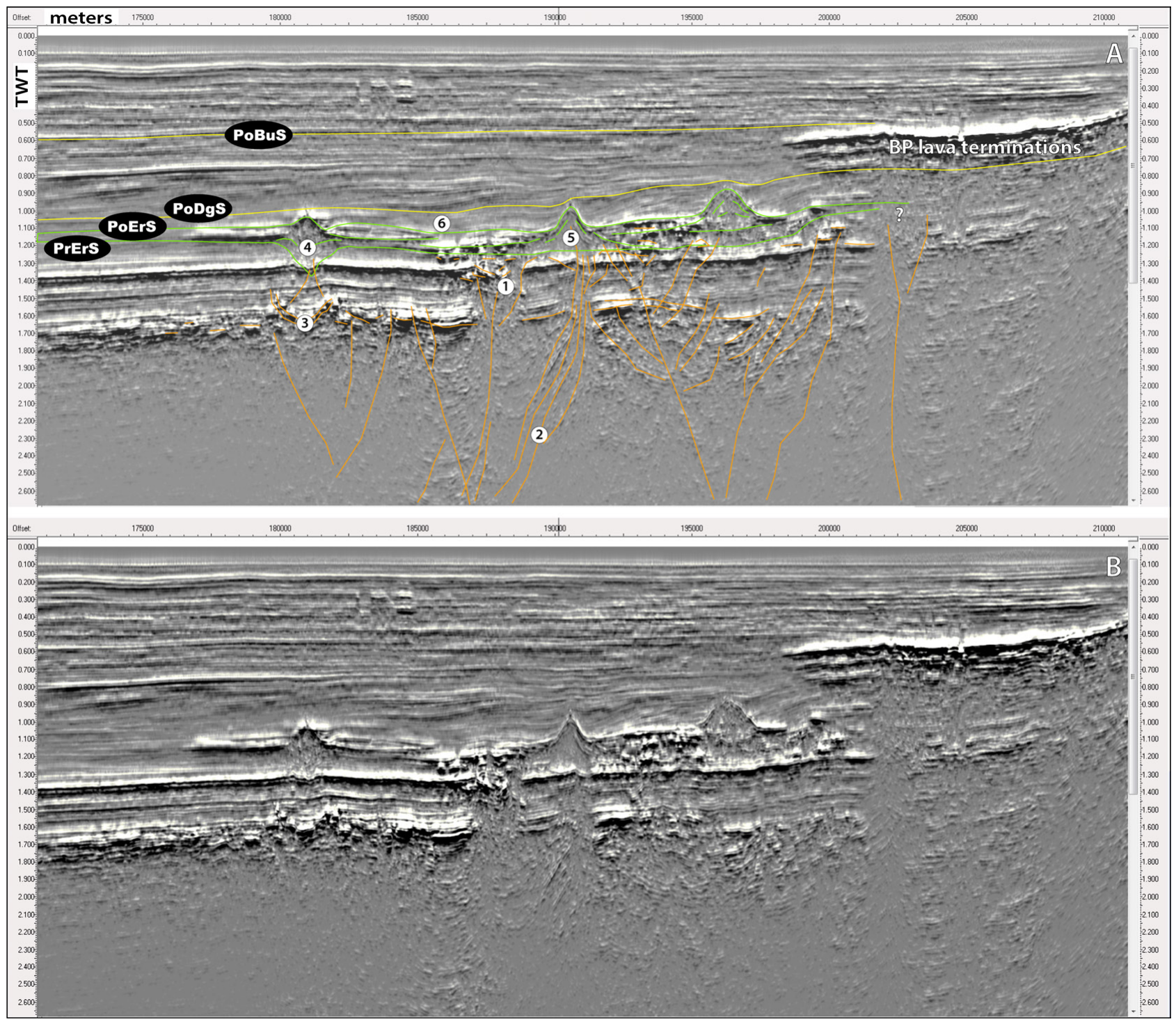

Figure 22: 2D strike-oblique section (line CB-82-15) showing the morphology of some of the volcanoes and part of the in the MVS plumbing system. BP abbreviation refer to Banks Peninsula volcanoes.

The processes that control the deposition of these fans remains poorly investigated, but are likely to involve either erosion around the burial dome, due to local formation of a hard seafloor substrate associated with the dome structure, or could be related to carbonate deposits at the top of the domes.

\section{Conclusions}

Reconstruction of the architecture of the Maahunui Volcanic System (MVS) enables us to understand how igneous and sedimentary bodies interact and are distributed in space and time within the northern part of Canterbury
Basin. MVS comprises 25 main intrusive, extrusive and sedimentary architectural elements that are systematically distribute into three first order magmatic sequences (i.e. pre-, syn-, and post magmatic). The architecture of the MVS resulted from four second order magmatic stages associated with (i) emplacement of magma at the subvolcanic level, (ii) construction of a volcanic sub-sea morphology, (iii) degradation, and (iv) burial of a monogenetic volcanic field in a sedimentary basin. The MVS plumbing system comprises mainly saucer-shaped sills, sill and dike swarms and minor laccoliths, divided systematically into five plumbing-types. The geometries and sizes of these intrusive architectural elements are determined by their level of emplacement, and by their spatial relationship 


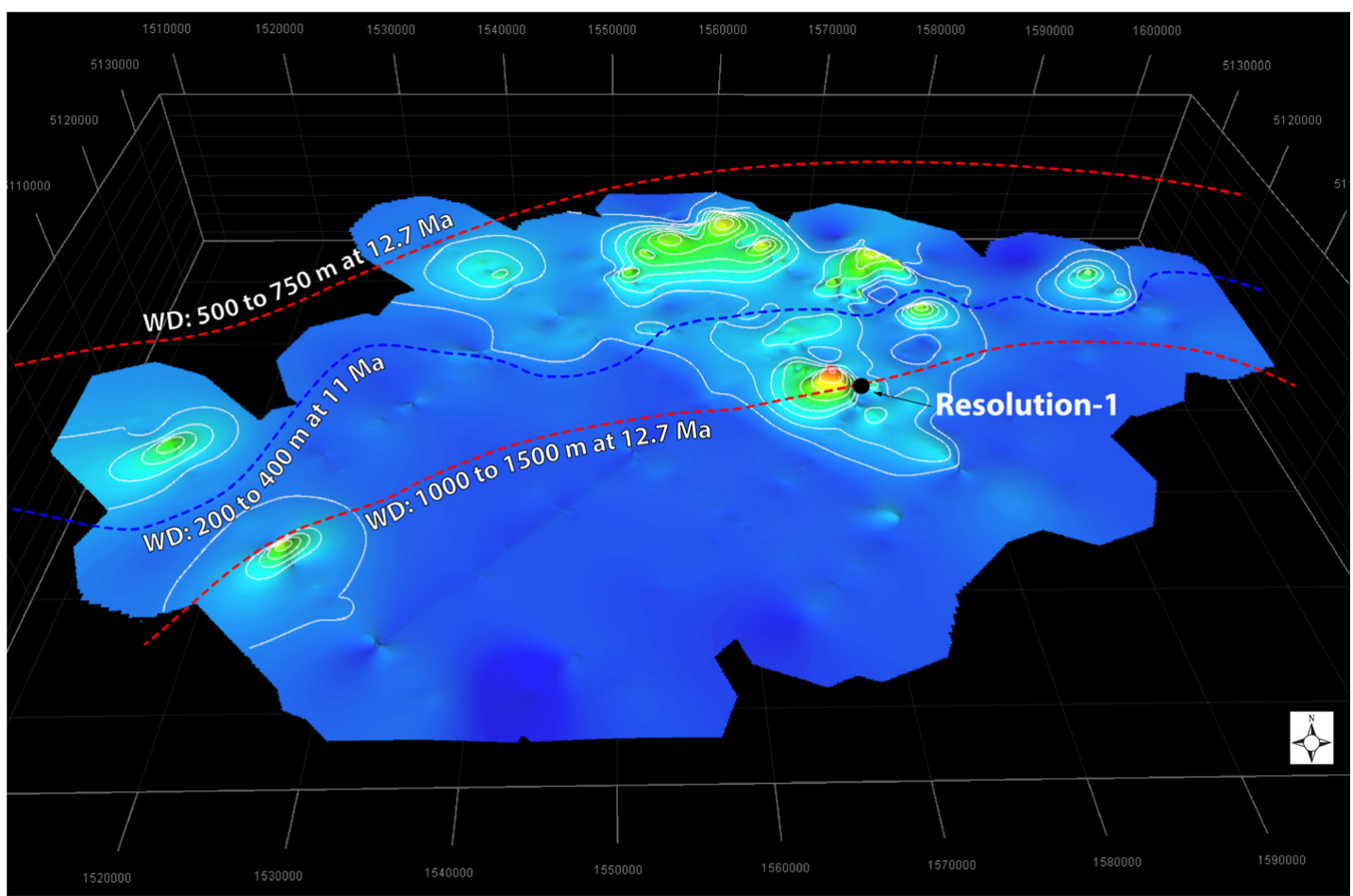

Figure 23: 3D view of the isochron map that represent the syn-magmatic sequence of the MVS. Rainbow colours are the equivalent thickness of this sequence and represent the paleogeography of the study area at $11.5 \mathrm{Ma}$. Red dashed lines show the approximate bathymetry at the onset of eruptions in the MVS (12.7 Ma). Blue dashed line shows the position of the shelf-break at $11 \mathrm{Ma}$.

to host sedimentary strata. The extrusive part of the volcanic field was erupted entirely in a deep marine setting (ca $1000 \mathrm{~m}$ water depth), and contains at least 31 deepwater equivalents to crater-type (i.e. maar-diatreme volcanoes), and cone-type volcanoes (i.e. tuff cones). Cratertype volcanoes have eight main syn-eruptive architectural elements: root zone, lower and upper diatreme, tephra ring and tephra plain, intra-crater cones, overspill wedge and tephra fallout carpet. Cone-type volcanoes have five main syn-eruptive architectural elements: basal cone, central crater, tephra flank, cone apron and tephra fallout carpet. Each of these syn-eruptive elements formed by a combination of eruptive and associated sedimentary deposits, with minor and localised intrusions. After volcanism ceased, degradation and burial of the volcanic edifices strongly affected local sedimentation for at least ca $6 \mathrm{Myr}$ after the volcanoes ceased erupting, and ca $1 \mathrm{Myr}$ after they were completely buried. Degradation and burial of the volcanic edifices of the MVS produced five main sedimentary architectural elements (i.e. inter-cone plains, epiclastic plumes, canyons and gullies, burial domes and seamount-edge fans). This study demonstrate the value of detailed seismic stratigraphic analysis coupled with information from borehole data, and analogy with volcanological processes that occur elsewhere. Understanding the time and space relationships between the diverse architectural elements permits us to reconstruct the complete architecture of the MVS, including its shallow $(<3 \mathrm{~km}$ ) plumbing system, morphology of volcanoes, and their impact on the host sedimentary basin during their degradation and burial. Insights from the architecture of the MVS can be used for exploration of geoenergy resources such as oil, gas and geothermal energy in buried and active monogenetic volcanic systems elsewhere.

Acknowledgement: We would like to thank IHS Markit and Schlumberger for providing academic licence to use the Kingdom and Petrel software. We are grateful to the New Zealand Petroleum and Minerals and the Ministry of Business, Innovation and Employment of New Zealand for providing the dataset and funding for this study. Thanks for the constructive reviews of Károly Németh and an anonymous reviewer.

\section{References}

[1] Bergman S.C., Talbot J.P., Thompson P.R., The Kora Miocene Submarine Andesite Stratovolcano Hydrocarbon Reservoir, Northern Taranaki Basin, New Zealand. In: New Zealand Oil Exploration 
Conference., 1991, 178-206

[2] Herzer R.H., Seismic Stratigraphy of a Buried Volcanic Arc, Northland, New Zealand and Implications for Neogene Subduction. Mar. Pet. Geol., 1995, 12 (5), 511-31. https://doi.org/10.1016/ 0264-8172(95)91506-K

[3] Planke S., Alvestad E., Eldholm O., Seismic Characteristics of Basaltic Extrusive and Intrusive Rocks. The Leading Edge., 1999, 18 (3), 342 https://doi.org/10.1190/1.1438289

[4] Holford S.P., Schofield N., MacDonald J.D., Duddy I.R., Green P.F., Seismic Analysis of Igneous Systems in Sedimentary Basins and Their Impacts on Hydrocarbon Prospectivity: Examples from the Southern Australian Margin. APPEA Journal., 2012, 52, 229-52

[5] Schofield N., Heaton L., Holford S.P., Archer S.G., Jackson C.A.L., Jolley D.W., Seismic imaging of "broken bridges": linking seismic to outcrop-scale investigations of intrusive magma lobes. J Geol Soc., 2012, doi:10.1144/0016-76492011-150.

[6] Bischoff A.P., Nicol A., Beggs M., Stratigraphy of architectural elements in a buried volcanic system and implications for hydrocarbon exploration. Interpretation., 2017. https://doi.org/10.1190/INT-2016-0201.1

[7] Lister, J. R., \& Kerr, R. C. (1991). Fluid-Mechanical Models of Crack Propagation and Their Application to Magma Transport in Dykes. J Geophys Res, 96(B6), 10049-77.

[8] Rubin, A. M. (1995). Propagation of Magma-Filled Cracks. Annual Review Of Earth And Planetary Sciences, 23, 287-336.

[9] O'Neill, C., \& Spiegelman, M. (2010). Formulations for Simulating the Multiscale Physics of Magma Ascent. Dosseto A, Turner SP, van Orman JA, editors. Timescales of Magmatic Processes: From Core to Atmosphere. Chichester, UK. : John Wiley \& Sons, Ltd, 87-101.

[10] Kereszturi G., Németh K., Monogenetic Basaltic Volcanoes: Genetic Classification, Growth, Geomorphology and Degradation. Updates in Volcanology - New Advances in Understanding Volcanic Systems., 2012, https://doi.org/10.5772/51387

[11] Cas R.A.F., Wright J.V., Volcanic Successions: Modern and Ancient - A Geological Approach to Processes, Products and Successions. Chapman and Hall, UK, 1993, https://doi.org:10.1007/978-0412-44640-5

[12] Kereszturi G., Németh K., Csillag G., Balogh K., Kovács J., The role of external environmental factors in changing eruption styles of monogenetic volcanoes in a Mio/Pleistocene continental volcanic field in western Hungary., 2011, 227-240. doi:10.1016/j.jvolgeores.2010.08.018

[13] Silva S.D., Lindsay J.M., Primary Volcanic Landforms. In: Sigurdsson H. (Ed.), The Encyclopedia of Volcanoes. Elsevier, 2015, https://doi.org/10.1016/B978-0-12-385938-9.00015-8

[14] Rogers N., Chapter 4 - The Composition and Origin of Magmas. In: Sigurdsson H. (Ed.), The Encyclopedia of Volcanoes, Elsevier, 2015, doi:10.1016/B978-0-12-385938-9.00004-3

[15] Planke S., Millett J.M., Maharjan D., Jerram D.A., Abdelmalak M.M., Groth A., Hoffmann J., Berndt C., Myklebust R., Igneous seismic geomorphology of buried lava fields and coastal escarpments on the Vøring volcanic rifted margin. Interpretation., 2017, https://doi.org/10.1190/INT-2016-0164.1

[16] Planke S, Alvestad E, Eldholm O (1999) Seismic Characteristics of Basaltic Extrusive and Intrusive Rocks. The Leading Edge 18: 342. https://doi.org/10.1190/1.1438289

[17] Schutter S.R., Hydrocarbon Occurrence and Exploration in and around Igneous Rocks. Geological Society, London, Special Publications., 2003, 214 (1), 7-33.
doi:10.1144/GSL.SP.2003.214.01.02

[18] Rohrman M., Prospectivity of Volcanic Basins: Trap Delineation and Acreage de-Risking. AAPG Bulletin., 2007, 91 (6), 915-39., doi:10.1306/12150606017

[19] Schofield N, Jerram DA, Holford S, Stuart A, Niall M, Hartley A, Howell J, David M, Green P, Hutton D, Stevenson C (2016) Sills in sedimentary basin and petroleum systems: In Németh K (ed) The Series Advances in Volcanology, pp 1-22.

[20] Reynolds P., Holford S., Schofield N., Ross A., Three-Dimensional Seismic Imaging of Ancient Submarine Lava Flows: An Example From the Southern Australian Margin. Geochem. Geophys. Geosys., 2017, doi:10.1002/2017GC007178

[21] Lorenz V., Maars and diatremes of phreatomagmatic origin, a review. T. Geol. Soc. South Africa., 1985, 88, 459-470

[22] Orton G.J., Volcanic Environments. In: Reading H.G., Sedimentary Environments: Processes, Facies and Stratigraphy., 1996, 688

[23] Kereszturi G., Csillag G., Németh K., Sebe K., Balogh K., Jáger V., Volcanic architecture, eruption mechanism and landform evolution of a Plio/Pleistocene intracontinental basaltic polycyclic monogenetic volcano from the Bakony-Balaton Highland Volcanic Field, Hungary. Central European J. Geosci., 2010 doi:10.2478/v10085-010-0019-2

[24] Németh K., Monogenetic volcanic fields; origin, sedimentary record, and relationship with polygenetic volcanism. Special Paper Geological Society of America., 2010, https://doi.org/10.1130/2010.2470(04)

[25] Németh K, Kereszturi G (2015) Monogenetic volcanism: personal views and discussion. Int J Earth Sci (Geol Rundsch) 104: 2131. https://doi.org/10.1007/s00531-015-1243-6

[26] White J.D.L., The depositional record of small, monogenetic volcanoes within terrestrial basins, in Sedimentation in volcanic settings. In: Fisher R.V., Smith G.A., (Ed.), Sedimentation in Volcanic Settings. SEPM Spec. Publ., 1991, 45, 155-171

[27] Muirhead J.D., Van Eaton A.R., Re G., White J.D.L., Ort M.H., Monogenetic volcanoes fed by interconnected dikes and sills in the Hopi Buttes volcanic field, Navajo Nation, USA. Bull Volcanol., 2016 doi:10.1007/s00445-016-1005-8

[28] White J.D.L., Ross P.S., Maar-diatreme volcanoes: A review., 2011, https://doi.org/10.1016/j.jvolgeores.2011.01.010

[29] White JDL, Ross PS (2011) Maar-diatreme volcanoes: A review. https://doi.org/10.1016/j.jvolgeores.2011.01.010

[30] Jerram D.A., Single R.T., Hobbs R.W., Nelson C.E., Understanding the offshore flood basalt sequence using onshore volcanic facies analogues: An example from the Faroe-Shetland basin. Geol. Mag., 2009, https://doi.org/10.1017/S0016756809005974

[31] Rabbel O., Galland O., Mair K., Lecomte I., Senger K., Spacapan J.B., Manceda R., From field analogues to realistic seismic modelling: a case study of an oil-producing andesitic sill complex in the Neuquén Basin, Argentina. J. Geol. Soc., 2018, doi:10.1144/jgs2017-116

[32] Millett J., Wilkins A., Campbell E., Hole M., Taylor R., Healy D., Jerram D., Jolley D., Planke S., Archer S., Blischke A., The geology of offshore drilling through basalt sequences: Understanding operational complications to improve efficiency., 2016, doi:10.1016/j.marpetgeo.2016.08.010

[33] Reynolds P., Schofield N., Brown R.J., Holford S.P., The architecture of submarine monogenetic volcanoes - insights from 3D seismic data. Bas. Res., 2016, 30, 437-45. doi:10.1111/bre.12230

[34] McLean C.E., Schofield N., Brown D.J., Jolley D.W., Reid A., 3D seismic imaging of the shallow plumbing system beneath the 
Ben Nevis Monogenetic Volcanic Field: Faroe-Shetland Basin: J. Geol. Soc., 2017, https://doi.org/10.1144/igs2016-118

[35] Bischoff AP, Rossetti M, Nicol A, Kennedy B (2019a) Seismic Reflection and Petrographic Interpretation of a Buried Monogenetic Volcanic Field (Part 1). Bull Volcanol 81: 56. https://doi.org/10. 1007/s00445-019-1316-7

[36] Galland O., Bertelsen H.S., Eide C.H., Guldstrand F., Haug Ø.T., Héctor, Leanza A., Mair K., Palma O., Planke S., Rabbel O., Rogers B., Schmiedel T., Souche A., Spacapan J.B., Storage and transport of magma in the layered crust-Formation of sills and related floatlying intrusions. In: Burchardt S., (Ed.), Volcanic and Igneous Plumbing Systems, Elsevier., 2018, 111-136

[37] Pittari A., Cas R.A.F., Lefebvre N., Robey J., Kurszlaukis S., Webb K., Eruption processes and facies architecture of the Orion Central kimberlite volcanic complex, Fort à la Corne, Saskatchewan; kimberlite mass flow deposits in a sedimentary basin. J. Volcanol. Geotherm. Res., 2008, 174 (1), 152-170., doi.org/10.1016/j.jvolgeores.2007.12.019

[38] Bischoff AP, Nicol A, Barrier A, Wang H (2019b) Paleogeography and Volcanic Morphology Reconstruction of a Buried Monogenetic Volcanic Field (Part 2). Bull Volcanol 81: 57. https://doi. org/10.1007/s00445-019-1317-6

[39] Huafeng T, Phiri C, Youfeng G, Yulong H, Weihua, B (2015) Types and Characteristics of Volcanostratigraphic Boundaries and Their Oil-Gas Reservoir Significance. Acta Geologica Sinica - English Edition, 89: 163-174.

[40] Bischoff A.P., Architectural Elements of Buried Volcanic Systems and Their Impact on Geoenergy Resources. Ph.D. Thesis, Canterbury University, New Zealand. Pre-print, 2019, 226, doi: 10.13140/RG.2.2.21440.58886

[41] Milne A.D., Well completion report Resolution, for BP, Shell, Todd Canterbury Service Limited. New Zealand Geological Survey Open-file Petroleum Report No. 648, 1975

[42] Suggate R.P., Stevens G.R., Te Punga M.T., The geology of New Zealand. Govt Printer, Wellington, 1978

[43] Carlson J.R., Grant-Mackie J.A., Rodgers K.A., Stratigraphy and sedimentology of the coalgate area, Canterbury, New Zealand: New Zeal. J. Geol. Geop., 1980, https://doi.org/10. 1080/00288306.1980.10424205

[44] Coombs D.S., Cas R.A., Kawachi Y., Landis C.A., McDonough W.F., Reay A., Cenozoic volcanism in north, east and central Otago. In: Smith, I.E.M. (Ed.), Late Cenozoic Volcanism in New Zealand. R. Soc. N.Z. Bull., 1986, 23, 278-312

[45] Sewell R.J., Late Miocene volcanic stratigraphy of central Banks Peninsula, Canterbury, New Zealand., 1988, 41-64, https://doi.org/10.1080/00288306.1988.10417809

[46] Field B.D., Browne G.H., Davy B.W., Herzer R.H., Hoskins R.H., Raine J.I., Wilson G.J., Sewell R.J., Smale D., Watters W.A., Cretaceous and Cenozoic sedimentary basins and geological evolution of the Canterbury region, South Island, New Zealand. Lower Hutt: New Zealand Geological Survey. New Zealand Geological Survey basin studies., 1989, 2, 94

[47] Németh K., White J.D.L., Reconstructing eruption processes of a Miocene monogenetic volcanic field from vent remnants: Waipiata Volcanic Field, South Island, New Zealand. J. Volcanol. Geotherm. Res., 2003, 124 (1-2), 1-21

[48] Finn C.A., Müller R.D., Panter K.S., A Cenozoic diffuse alkaline magmatic province (DAMP) in the southwest Pacific without rift or plume origin. Geochem. Geophys. Geosys., 2005, https://doi. org/10.1029/2004GC000723
[49] Timm C., Hoernle K., Werner R., Hauff F., van den Bogaard P., White J., Mortimer N., Garbe-Schönberg D., Temporal and geochemical evolution of the Cenozoic intraplate volcanism of Zealandia., 2010, doi:10.1016/j.earscirev.2009.10.002

[50] Barrier A., Nicol A., Bischoff A.P., Volcanism Occurrences in the Canterbury Basin, New Zealand and Implication for Petroleum Exploration. In: AAPG GTW Influence of Volcanism and Associated Magmatic Processes on Petroleum Systems. Conference, Oamaru, New Zealand., 2017

[51] Coombs D.S., White A.J.R., Hamilton D., Couper R.A., Age relations of the Dunedin volcanic complex and some paleogeographic implications-Part II. New Zealand J. Geol. Geophys., 1960, https://doi.org:10.1080/00288306.1960.10420145

[52] Blanke S.J., "Saucer Sills" of the Offshore Canterbury Basin. GNS Publication., 2012, https://doi.org:10.1177/0094306114545742f

[53] Bischoff A.P., Nicol A., Barrier A., Beggs M., The Stratigraphic Record of Volcanism - Examples from New Zealand Sedimentary Basins. In: Geoscience Society of New Zealand Conference, Wanaka, Abstract, 2016

[54] Barrier A., Tectonic, structure and sedimentary evolution of the Canterbury Basin, New Zealand. PhD Thesis, University of Canterbury, 2019

[55] Mitchum R.M., Vail P.R., Seismic Stratigraphy and Global Changes of Sea Level, Part 7: Seismic Stratigraphic Interpretation Procedure. Seismic Stratigraphy: Applications to Hydrocarbon Exploration. AAPG Memoir., 1977, 26, 135-43

[56] Posamentier, H. W., Vail P. R., 1988, Eustatic Controls on Clastic Deposition II - Sequence and Systems Track Models. In Sea-Level Changes. doi:10.2110/pec.88.01.0125.

[57] Van Wagoner J.C., Mitchum Jr R.M., Campion K.M., Rahmanian V.D., Siliciclastic Sequence Stratigraphy in Well Logs, Core, and Outcrops: Concepts for High-Resolution Correlation of Time and Facies. In: American Association of Petroleum Geologists, Methods in Exploration., 1990, Series 7, 55

[58] Catuneanu O., Principles of Sequence Stratigraphy. Changes., 2006, 375., https://doi.org:10.5860/CHOICE.44-4462

[59] Hunt D, Tucker ME (1992) Stranded parasequences and the forced regressive wedge systems tract: deposition during baselevel fall: Sediment Geol 81: 1-9. https://doi.org/10.1016/00370738(92)90052-S

[60] Catuneanu O., Bhattacharya J.P., Blum M.D., Dalrymple R.W., Eriksson P.G., Fielding C.R., Fisher W.L. et al., Sequence Stratigraphy: Common Ground after Three Decades of Development. First Break., 2010, doi:10.3997/1365-2397.2010002

[61] Catuneanu O., Abreu V., Bhattacharya J.P., Blum M.D., Dalrymple R.W., Eriksson P.G., Fielding C.R., et al., Towards the standardization of sequence stratigraphy. Earth. Sci. Rev., 2009, 92, 1-33., doi:10.1016/j.earscirev.2008.10.003

[62] Smith G.A., 1991, Facies sequences and geometries in continental volcaniclastic sequences in Fisher, R.V., and Smith, G.A., eds., Sedimentation in volcanic settings: SEPM (Society for Sedimentary Geology) Special Publication 45, p. 109-121.

[63] Palladino, D M, S. Simei, G. Sottili., 2010, Integrated approach for the reconstruction of stratigraphy and geology of Quaternary volcanic terrains: An application to the Vulsini Volcanoes (central Italy). Geological Society of America Special Papers, 2010, 464, p. 63-84, doi:10.1130/2010.2464(04)

[64] Karaoglu, O. and Helvaci, C., 2012. Growth, destruction and volcanic facies architecture of three volcanic centres in the Miocene Usak-Gure basin, western Turkey: Subaqueous-subaerial volcan- 
ism in a lacustrine setting. Journal of Volcanology and Geothermal Research, 245: 1-20.

[65] Martí, J., Groppelli, G. and Brum da Silveira, A., 2018. Volcanic stratigraphy: A review. Journal of Volcanology and Geothermal Research, 357: 68-91.

[66] Lucchi, F., 2019. On the use of unconformities in volcanic stratigraphy and mapping: Insights from the Aeolian Islands (southern Italy). Journal of Volcanology and Geothermal Research, https://doi.org/10.1016/j.jvolgeores.2019.01.014.

[67] Németh, K. and Palmer, J., 2019. Geological mapping of volcanic terrains: Discussion on concepts, facies models, scales, and resolutions from New Zealand perspective. Journal of Volcanology and Geothermal Research, https://doi.org/10.1016/j.jvolgeores. 2018.11.028

[68] Allen J.R.L., Studies in Fluviatile Sedimentation: Bars, BarComplexes and Sandstone Sheets (Low-Sinuosity Braided Streams) in the Brownstones (L. Devonian), Welsh Borders. Sediment. Geol., 1983, 33 (4), 237-93., doi:10.1016/00370738(83)90076-3.

[69] Miall A.D., Architectural-Element Analysis: A New Method of Facies Analysis Applied to Fluvial Deposits. Earth Sci. Rev. Elsevier Science Publishers., 1985, (BV 22), 261-308., doi:10.1016/00128252(85)90001-7

[70] Mutti E., Normark W.R., Comparing Examples of Modern and Ancient Turbidite Systems: Problems and Concepts. Marine Clastic Sedimentology., 1987, doi:10.1007/978-94-009-3241-8_1

[71] Miall A.D., Tyler N., Three-Dimensional Facies Architecture of Terrigenous Clastic Sediments and Its Implications for Hydrocarbon Discovery and Recovery. SEPM (Society for Sedimentary Geology)., 1991, 1-5., doi:10.2110/csp.91.03.0001

[72] Miall A.D., Principles of Sedimentary Basin Analysis. SpringerVerlag, New York, 616, 2000

[73] Borghi, L., 2000, Visão geral da análise de fácies do ponto de vista da arquitetura deposicional. Boletim do Museu Nacional. Nova Série Geologia, Rio de Janeiro, v. 53, n.58, p. 1-26.

[74] Posamentier H.W., Kolla V., Seismic Geomorphology and Stratigraphy of Depositional Elements in Deep-Water Settings. J. Sed. Res., 2003, 73 (3), 367-88., doi:10.1306/111302730367

[75] Slatt R.M., Stratigraphic Reservoir Characterization for Petroleum Geologists. Developments in Petroleum Science., 2013, doi:10.1016/B978-0-444-56365-1.00013-4

[76] Moraes M.A.S., Blaskovski P.R., Paraizo P.L.B., Arquitetura de Reservatórios de Águas Profundas. Boletim de Geociencias Da Petrobras. 2006

[77] Gamboa D., Alves T.M., Spatial and Dimensional Relationships of Submarine Slope Architectural Elements: A Seismic-Scale Analysis from the Espírito Santo Basin (SE Brazil). Marine Pet. Geol., 2015, doi:10.1016/j.marpetgeo.2015.02.035.

[78] Kendall C.G.C., Tucker M.E., SEPM STRATA website. 2010, http://www.sepmstrata.org/page.aspx?pageid=410

[79] Catuneanu O., Galloway W.E., St. C.G., Kendall C., Miall A.D., Posamentier H.W., Strasser A., Tucker M.E., Sequence Stratigraphy: Methodology and Nomenclature. Newsletters on Stratigraphy., 2011, doi:10.1127/0078-0421/2011/0011

[80] Liu J., Hou Y., Li Y., Dong X., Wang X., Characterisation of architectural elements of Ordovician fractured-cavernous carbonate reservoirs, Tahe Oilfield, China. J. Geol. Soc. India., 2018, 91 (3), 315-322

[81] Planke S., Rasmussen T., Rey S.S., Myklebust R., Seismic characteristics and distribution of volcanic intrusions and hydrothermal vent complexes in the Vøring and Møre basins, in Petroleum Geology: North-West Europe and Global Perspectives - Proceedings of the 6th Petroleum Geology Conference., 2005, doi:10.1144/0060833.

[82] Hansen D.M., Cartwright J., Saucer-Shaped Sill with Lobate Morphology Revealed by 3D Seismic Data: Implications for Resolving a Shallow-Level Sill Emplacement Mechanism. J. Geol. Soc., 2005, 163 (3), 509-23., https://doi.org/10.1144/0016-764905-073

[83] Jackson C.A.L., Seismic reflection imaging and controls on the preservation of ancient sill-fed magmatic vents. J. Geol. Soc., 2012, https://doi.org/10.1144/0016-76492011-147

[84] Schmiedel T., Kjoberg S., Planke S., Magee C., Galland O., Schofield N., Jackson C.A.L., Jerram D.A., Mechanisms of overburden deformation associated with the emplacement of the Tulipan sill, mid-Norwegian margin. Interpretation., 2017, doi:10.1190/INT-2016-0155.1

[85] Senger K., Millett J., Planke S., Ogata K., Eide C., Festøy M., Galland O., Jerram D., Effects of igneous intrusions on the petroleum system: a review. First Break, 2017, 35, 47-56., 10.3997/13652397.2017011

[86] Montanari D., Bonini M., Corti G., Agostini A., Ventisette C., Forced folding above shallow magma intrusions: Insights on supercritical fluid flow from analogue modelling., 2017, doi:10.1016/j.jvolgeores.2017.07.022

[87] Németh, K. and Martin, U., 2007. Shallow sill and dyke complex in western Hungary as a possible feeding system of phreatomagmatic volcanoes in "soft-rock" environment. Journal of Volcanology and Geothermal Research, 159(1-3): 138-152.

[88] Re, G., White, J.D.L., Muirhead, J.D. and Ort, M.H., 2016. Subterranean fragmentation of magma during conduit initiation and evolution in the shallow plumbing system of the small-volume Jagged Rocks volcanoes (Hopi Buttes Volcanic Field, Arizona, USA). Bulletin of Volcanology, 78(8).

[89] Schofield N., Stevenson C., Reston T., Magma fingers and host rock fluidization in the emplacement of sills. Geology., 2010, 38, 63-66. 10.1130/G30142.1.

[90] Martin, U. and Nemeth, K., 2007. Blocky versus fluidal peperite textures developed in volcanic conduits, vents and crater lakes of phreatomagmatic volcanoes in Mio/Pliocene volcanic fields of Western Hungary. Journal of Volcanology and Geothermal Research, 159(1-3): 164-178.

[91] Németh, K. and White, C.M., 2009. Intra-vent peperites related to the phreatomagmatic 71 Gulch Volcano, western Snake River Plain volcanic field, Idaho (USA). Journal of Volcanology and Geothermal Research, 183(1-2): 30-41.

[92] Jackson, C. A.-L., 2012, Seismic reflection imaging and controls on the preservation of ancient sill-fed magmatic vents: Journal of the Geological Society, doi:10.1144/0016-76492011-147.

[93] Sversen H.H., Torsvik T.H., Callegaro S., Augland L., Heimdal T.H., Jerram D.A., Planke S., Pereira E., Gondwana Large Igneous Provinces: plate reconstructions, volcanic basins and sill volumes. Geological Society, London, Special Publications., 2017, doi:10.1144/SP463.7

[94] Infante-Paez L., Marfurt K.J., Seismic expression and geomorphology of igneous bodies: A Taranaki Basin, New Zealand, case study. Interpretation., 2017, 5 (3), SK121-SK140., https://doi.org/10.1190/INT-2016-0244.1

[95] Morley C., 3D seismic imaging of the plumbing system of the Kora volcano, Taranaki Basin, New Zealand: The influences of syn-rift structure on shallow igneous intrusion architecture. Geosphere., 
2018, doi.org/10.1130/GES01645.1

[96] Macdonald R., (2003) Magmatism of the Kenya Rift Valley: A review. Transactions of the Royal Society of Edinburgh. Earth Sciences., 2003, 239-253., doi:10.1017/S0263593300000420

[97] Chorowicz J., The East African rift system: J. African Earth Sci., 2005, 43 (1), 379-410., doi: https://doi.org/10.1016/j.jafrearsci. 2005.07.019

[98] Ring U., The East African rift system. Austrian Journal of Earth Sciences., 2014, doi:10.1016/j.jafrearsci.2005.07.019

[99] White J.D.L., Subaqueous eruption-fed density currents and their deposits: Precambrian Research., 2000, 101, 87-109., https: //doi.org/10.1016/S0301-9268(99)00096-0

[100] Németh K., Kereszturi G., Monogenetic volcanism: personal views and discussion. Int. J. Earth. Sci. (Geol Rundsch)., 2015, 104, 2131., https://doi.org/10.1007/s00531-015-1243-6

[101] Cas R.A.F., Landis C.A., Fordyce R.E., A monogenetic, Surtlatype, Surtseyan volcano from the Eocene-Oligocene WaiarekaDeborah volcanics, Otago, New Zealand: A model. Bull. Volcanol., 1989, 51 (4), 281-298

[102] White J.D.L., Pre-emergent construction of a lacustrine basaltic volcano, Pahvant Butte, Utah (USA). Bull. Volcanol., 1996, 58, 249-262

[103] Lorenz V., Kurszlaukis S., Root Zone Processes in the Phreatomagmatic Pipe Emplacement Model and Consequences for the Evolution of Maar-Diatreme Volcanoes. J. Volcanol. Geotherm. Res., 2007, 159, 4-32

[104] Kaulfuss U., Németh K., White J., Field Guide Miocene subaerial to subaqueous monogenetic volcanism in Otago, New Zealand., 2012

[105] Jones A.D., Wilson G., Gorman A., Fox B., Lee D., Kaulfuss U., A drill-hole calibrated geophysical characterisation of the 23 Ma Foulden Maar stratigraphic sequence, Otago, New Zealand., 2017, 1-13., https://doi.org/10.1080/00288306.2017.1369130

[106] Fiske R.S., Cashman K.V., Shibata A., Watanabe K., Tephra dispersal from Myojinsho, Japan, during its shallow submarine eruption of 1952-1953. Bull. Volcanol., 1998, 59, 262-275., doi:10.1007/s004450050190.

[107] Bonadonna C., Mayberry G.C., Calder E.S., Sparks R.S.J., Choux C., Jackson P., Lejeune A.M., et al., Tephra fallout in the eruption of Soufrière Hills Volcano, Montserrat: Geological Society, London, Memoirs., 2002 doi:10.1144/GSL.MEM.2002.021.01.22.

[108] Manville, V. and Wilson, C.J.N., 2004. Vertical density currents: a review of their potential role in the deposition and interpretation of deep-sea ash layers. Journal Of The Geological Society, 161: 947-958.

[109] Manville, V., Nemeth, K. and Kano, K., 2009. Source to sink: A review of three decades of progress in the understanding of volcaniclastic processes, deposits, and hazards. Sedimentary Geology, 220(3-4): 136-161.

[110] Deardorff N.D, Cashman K.V, Chadwick W.W., 2011 Observations of eruptive plume dynamics and pyroclastic deposits from submarine explosive eruptions at NW Rota-1, Mariana arc. J Volcanol Geotherm Res.

[111] Cas R.A.F., Giordano G., Submarine volcanism: A review of the constraints, processes and products, and relevance to the Cabo de Gata volcanic succession., 2014, https://doi.org:10.3301/IJG. 2014.46

[112] Zimanowski B., Büttner R., Lorenz V., Häfele H.G., Fragmentation of basaltic melt in the course of explosive volcanism. J. Geophys. Res. Solid Earth., 1997, doi:10.1029/96JB02935
[113] Zimanowski B., Büttner R., Phreatomagmatic explosions in subaqueous volcanism, in Geophysical Monograph Series., 2003, doi:10.1029/140GM03

[114] White J.D.L., Valentine G.A., Magmatic versus phreatomagmatic fragmentation: Absence of evidence is not evidence of absence. Geosphere., 2016, https://doi.org/10.1130/GES01337.1

[115] Clague D., Batiza R., Head J.W., Davis A., Pyroclastic and Hydroclastic Deposits on Loihi Seamount, Hawaii. In: White J.D.L., Smellie J.L., Clague D.A., (Ed.), Explosive Subaqueous Volcanism. American Geophysical Union, Washington D.C., 200. Bull. Volcanol., 2000a, https://doi.org/10.1029/140GM05

[116] Jamtveit B., Svensen H., Podladchikov J.J., Planke S., Hydrothermal vent complexes associated with sill intrusions in sedimentary basins. Geol. Soc. Lond. Spec., 2004, 234, 233-241

[117] Svensen H., Planke S., Malthe-Sorenssen A., Jamtveit B., Myklebust R., Eidem T.R., Rey S.S., Release of methane from a volcanic basin as a mechanism for initial Eocene global warming. Nature., 2004, 429, 542-545

[118] Hansen D.M., The morphology of intrusion-related vent structures and their implications for constraining the timing of intrusive events along the NE Atlantic Margin. J. Geol. Soc., 2006, 16, 789-800

[119] Agirrezabala L., Sarrionandia F., Carracedo M., Diatremeforming volcanism in a deep-water faulted basin margin: Lower Cretaceous outcrops from the Basque-Cantabrian Basin, western Pyrenees. J. Volcanol. Geotherm. Res., 2017. https://doi.org/10.1016/j.jvolgeores.2017.03.019

[120] McLean CE, Schofield N, Brown DJ, Jolley DW, Reid A (2017) 3D seismic imaging of the shallow plumbing system beneath the Ben Nevis Monogenetic Volcanic Field: Faroe-Shetland Basin: J Geol Soc. https://doi.org/10.1144/jgs2016-118

[121] Corcoran P.L., Moore L.N., (2008) Subaqueous eruption and shallow-water reworking of a small-volume Surtseyan edifice at Kakanui, New Zealand: Canadian J, Earth Sci,, 2008, 45 (12), 1469-1485

[122] Moorhouse B.L., White J.D.L., Scott J.M., Cape Wanbrow: A stack of Surtseyan-style volcanoes built over millions of years in the Waiareka-Deborah volcanic field, New Zealand. J. Volcanol. Geotherm. Res., 2015, doi:10.1016/j.jvolgeores.2015.03.019

[123] Di Capua A., Groppelli G., Emplacement of pyroclastic density currents (PDCs) in a deep-sea environment: The Val d'Aveto Formation case (Northern Apennines, Italy). J. Volcanol. Geotherm. Res., 2016, doi:10.1016/j.jvolgeores.2016.08.003

[124] Pope E.L., Jutzeler M., Cartigny M.J.B., Shreeve J., Talling P.J., Wright I.C., Wysoczanski R.J., Origin of spectacular fields of submarine sediment waves around volcanic islands. Earth Planet Sci. Lett., 2018, doi:10.1016/j.epsl.2018.04.020

[125] Rotella M.D., Wilson C.J.N., Barker S.J., Wright I.C., Highly vesicular pumice generated by buoyant detachment of magma in subaqueous volcanism. Nature Geoscience., 2013, doi:10.1038/nge01709

[126] Cas R.A.F., Simmons J.M., Why Deep-Water Eruptions Are So Different From Subaerial Eruptions. Front. Earth Sci., 2018, 6, 198., doi:10.3389/feart.2018.00198

[127] Chadwick, W.W., Nooner, S.L., Butterfield, D.A., and Lilley, M.D., 2012, Seafloor deformation and forecasts of the April 2011 eruption at Axial Seamount: Nature Geoscience, v. 5, p. 474-477, doi:10.1038/ngeo1464.

[128] Shumaker L., Sharman G., King P., Graham S., The source is in the sink: Deep-water deposition by a submarine volcanic 
arc, Taranaki Basin, New Zealand. Sedimentology., 2018, 65., 10.1111/sed.12475

[129] Corcoran, P. L., L. N. Moore., 2008, Subaqueous eruption and shallow-water reworking of a small-volume Surtseyan edifice at Kakanui, New Zealand: Canadian Journal of Earth Sciences, v. 45, no. 12, p. 1469-1485.

[130] Connor, C.B., and Hill, B.E., 1995, Three nonhomogeneous Poisson models for the probability of basaltic volcanism: Application to the Yucca Mountain region, Nevada: Journal of Geophysical Research, v. 100, p. 10107-10125.

[131] Hintz, A.R., 2008, Physical Volcanology and Hazard Analysis of a Young Monogenetic Volcanic Field: Black Rock Desert, Utah [MS thesis]: Tampa, University of South Florida, $142 \mathrm{p}$.

[132] Condit, C.D., 2010, Dynamic Digital Map of the Springerville Volcanic Field and the DDM-Template: An example of an opensource tool to distribute maps, data, articles, and multi-media materials: Geosphere, v. 6, p. 430-443.

[133] Kiyosugi, K., Connor, C. B., Zhao, D., Connor, L. J., and Tanaka, K., 2010, Relationships between volcano distribution, crustal structure, and P-wave tomography: an example from the Abu Monogenetic Volcano Group, SW Japan: Bulletin of Volcanology, v. 72 , p. 331-340.
[134] Kiyosugi K., Temporal and Spatial Analysis of Monogenetic Volcanic Fields. PhD theses. 2012, https://scholarcommons.usf. edu/etd/4101

[135] Holford S., Schofield N., Reynolds P., Subsurface fluid flow focused by buried volcanoes in sedimentary basins: Evidence from 3D seismic data, Bass Basin, offshore southeastern Australia., 2017, 39-50., doi:10.1190/INT-2016-0205.1.

[136] Forsyth P.J., Barrell D.J.A., Jongens R., (2008) Geology of the Christchurch area. Institute of Geological and Nuclear Sciences 1:250,000 Geological Map 16. Lower Hutt, GNS Science., 2008, $67 \mathrm{p} 1$ sheet

[137] Schiøler P., Raine J.I., Griffin A., Hollis C.J., Kulhanek D.K., Morgans H.E.G., Roncaglia L., Strong C.P., Uruski C., Revised biostratigraphy and well correlation, Canterbury Basin, New Zealand. GNS Science Consultancy Report 2011/12., 142 